\title{
The undrained strength - liquidity index relationship
}

Re-submitted to Canadian Geotechnical Journal

\section{Technical Paper}

Dr P. J. Vardanega, BE(Hons) MEngSc Qld.UT PhD Cantab., MIEAust M.ASCE

Lecturer in Civil Engineering,

Department of Civil Engineering

University of Bristol,

United Kingdom

Formerly, Research Associate

Department of Engineering

University of Cambridge

United Kingdom

p.j.vardanega@,bristol.ac.uk

Dr S. K. Haigh, MEng MA PhD Cantab.

University Lecturer in Geotechnical Engineering

Department of Engineering

University of Cambridge

United Kingdom

skh20@cam.ac.uk

Date version drafted:

$21^{\text {st }}$ January 2014

No. of words

5,200 (main text)

No. of tables

4

No. of figures

9 


\title{
The undrained strength - liquidity index relationship
}

\author{
P. J. Vardanega and S. K. Haigh
}

\begin{abstract}
A database of 641 fall cone tests on 101 soil samples from twelve countries has been analysed to determine the best mathematical relationship linking undrained shear strength with liquidity index. From the database, it is shown that the use of a linear relationship linking liquidity index and the logarithm of undrained shear strength that uses the commonly assumed 100-fold factor increase in strength from liquid to plastic limit over-predicts the measured data of soil strength. The use of a factor of about 35 for the ratio between the strength at liquid limit and that extrapolated to plastic limit is shown to be more realistic. Logarithmic liquidity index is examined and found to also correlate strongly with the logarithm of undrained shear strength, however it is shown that no great statistical improvement is present compared with the semilogarithmic formulation. When considering data of individual soils a power law fitting is shown statistically to be the preferred mathematical function.
\end{abstract}

\section{Keywords:}

fall cone tests; clay strength; soil classification; Atterberg limits; statistical analysis; liquidity index; logarithmic liquidity index 


\title{
The undrained strength - liquidity index relationship
}

\author{
P. J. Vardanega and S. K. Haigh
}

\section{INTRODUCTION}

Atterberg (1911a, 1911b) described seven qualitative limits that describe changes in the behaviour of cohesive soils with varying water content. The original terms from the German and Swedish versions of Atterberg's paper and the translations given by Casagrande (1932) are shown in Table 1. Of these limits, only the liquid and plastic limits, which determine the range of plastic behaviour of the soil, and the shrinkage limit have remained in common usage; the liquid limit being an assessment of the water content at which the soil begins to flow and the plastic limit test being an assessment of the brittle/ductile transition of the material. Whilst standardised tests for the liquid limit correspond to a fixed strength in the case of the fall-cone test, (Koumoto \& Houlsby, 2001), or a fixed specific strength (Haigh, 2012) in the case of the percussion test, the thread-rolling plastic limit test does not correspond to a fixed value of shear strength (Whyte, 1982; Haigh et al. 2013).

The measured values for the liquid and plastic limits of soils are widely used as index parameters. They are used to compute the plasticity index, which can be empirically correlated against many soil properties in geotechnical design. Perhaps the most famous of these correlations is Casagrande's A-line which classifies soils into clays and silts based on a correlation between soil type and a combination of liquid limit and plasticity index (Casagrande, 1947). The plasticity index has been used to predict undrained shear strength (Skempton, 1954 and 1957); the ratio of strength to Standard Penetration Test (SPT) blowcount (Stroud, 1974 ) and even critical state Cam-Clay parameters (Schofield \& Wroth, 1968; Lawrence, 1980 and Nakase et al., 1988).

The undrained strength of clays has been widely related to the liquidity index $I_{L}$, defined by equation (1):

$$
I_{L}=\frac{w-w_{p}}{w_{L}-w_{p}}
$$

Houston \& Mitchell (1969) proposed the limits on the remoulded strength of clay shown in Figure 1 based on data extracted from the literature. Latterly, several authors have proposed relationships between strength and liquidity index, while not explicitly recognising the band of strengths which exists in the data. Schofield \& Wroth (1968) upon examination of vane shear test data from Skempton \& Northey (1952) made the 
observation that 'from these data it appears that the liquid limit and plastic limit do correspond approximately to fixed strengths which are in the proposed ratio of 1:100'. Based on this observation, Wroth \& Wood, (1978) proposed equation (2):

$$
c_{u}=170 e^{-4.6 I_{L}}=1.7 \times 10^{2\left(1-I_{L}\right)} \quad \mathrm{kPa}
$$

This equation implies that the undrained shear strength of soil should be $1.7 \mathrm{kPa}$ at the liquid limit and 170 $\mathrm{kPa}$ at the plastic limit. An alternative correlation (equation 3) was proposed by Leroueil et al. (1983):

$$
c_{u}=\frac{1}{\left(I_{L}-0.21\right)^{2}} \quad \mathrm{kPa} \quad 0.5<I_{L}<2.5
$$

Whilst this equation fits the collected data presented in Leroueil et al (1983) well between liquidity indices of 0.5 and 2.5, it should obviously not be extrapolated below these values, as it predicts infinite strength at a liquidity index of 0.21 . Locat \& Demers (1988) suggested equation (4) for computing strengths at high liquidity indices. This equation was said to be valid for the range $1.5<I_{L}<6.0$.

$$
c_{u}=\left(\frac{1.167}{I_{L}}\right)^{2.44} \quad \mathrm{kPa} \quad 1.5<I_{L}<6.0
$$

For comparative purposes, Equations (2), (3), (4) are plotted on Figure 1 for the ranges in which they were reported to be valid in the original publications. O'Kelly (2013) also recently reviewed some of the many proposed empirical relationships linking water content and undrained shear strength.

Equation (2) was re-written by Wood (1990) in the form shown as equation (5):

$$
c_{u}=c_{L} R_{M W}^{\left(1-I_{L}\right)} \quad \mathrm{kPa}
$$

Wood (1990) postulated that $R_{M W}$ was a function of clay mineralogy, based on data from Dumbleton \& West (1970), being approximately 30 for kaolinitic soils and 100 for montmorillonitic soils. Other authors have also presented datasets that exhibit different values of $R_{M W}$. For example, Koumoto \& Houlsby (using a $60^{\circ}$, $60 \mathrm{~g}$ cone) presented data (albeit from only 6 clays) showing a value of approximately 44 as shown on Figure 2 for all their presented data with values for the individual soils varying from about 26 to 267 . Interestingly, Koumoto \& Houlsby (2001) retained the assumption of $R_{M W}=100$ in the subsequent analyses in their paper. On closer examination of the original vane shear test data from Skempton \& Northey (1952) used to justify the assumption of $R_{M W}=100$, even for these four clays the $R_{M W}$ value ranges from approximately 70 to 160 .

In this paper, it will be demonstrated, based on a large database, that the $R_{M W}$ value not only varies between soils but that an average value of around 35 is more appropriate, substantially less than the commonly assumed factor of 100. Fall cone strengths predicted from equation (2) will hence be un-conservative, 
especially at water contents closer to plastic limit. A detailed analysis comparing the standard semilogarithmic relationship and the power relationship linking fall cone undrained strength with water content will also be conducted.

\section{LIQUID LIMIT AND UNDRAINED STRENGTH}

\subsection{Casagrande's Liquid Limit}

Atterberg (1911a, 1911b) proposed a method for measuring the liquid limit of soils based on the stability of a groove in a clay bed when the soil container was struck on the hand. This method was standardised by Casagrande (1932) into the percussion technique which he subsequently criticised for its cumbersome nature (Casagrande, 1958). The method essentially relies on the inducement of a slope failure as the cup is 'tapped' - the water content when the 'canal' fails after 25 blows is the liquid limit.

It was recognised by Wroth (1979) and Wood (1990) that the Casagrande percussion test for liquid limit is determined by slope stability and liquid limit (measured this way) should therefore correspond to a fixed ratio of strength to density. Haigh (2012) performed a Newmarkian sliding block analysis of the test to show that this ratio is approximately $1 \mathrm{~m}^{2} / \mathrm{s}^{2}$. As soil density decreases with increasing water content, a soil with a high $w_{L}$ will exhibit a lower strength at liquid limit than those soils with lower liquid limits.

\subsection{The Fall Cone Test}

The fall cone test, developed by John Olsson in 1915 in Sweden, (Olsson, 1921; Hansbo, 1957 and Bjerrum \& Flodin, 1960) is a direct measurement of soil shear strength. This test was modified by Laboratoire Central des Ponts et Chaussées (LCPC) for bitumen testing (LCPC, 1966) and was introduced to the United Kingdom as a test for soils by Sherwood \& Ryley (1970). This test has become the standard test for liquid limit in the United Kingdom (BS1377, 1990) and a test supported in the Canadian practice (CAN/BNQ 1986; Leroueil \& Le Bihan, 1996). It is a mechanical test which removes the judgement that is required to determine failure when using the Casagrande cup but has been calibrated to give essentially the same results.

The British Standard test as described in BS1377 (1990) is essentially a hardness test in which an 80 gram cone with a $30^{\circ}$ cone angle penetrates $20 \mathrm{~mm}$ into a sample of soil. The soil strength at this point is reported in the literature to fall in the range 0.7 to $2.65 \mathrm{kPa}$ and was taken to be at the centre of this range, $(1.7 \mathrm{kPa})$, by Wroth \& Wood (1978). This strength criterion will be used in the analysis presented in this paper. 
Koumoto \& Houlsby (2001) give a detailed theoretical analysis of the mechanics of the fall cone test. This analysis shows the sensitivities in the test (cone angle, cone bluntness, surface roughness of the cone and cone heave).

The fall cone test can equally be used to measure the shear strength of soils at a range of water contents between liquid and plastic limits (e.g. Hansbo, 1957; Kyambadde, 2010 and Kyambadde \& Stone, 2012). At low moisture contents, the high strength of soils can cause problems due to low penetration with the standard cone. This problem has been addressed using pseudo-static cones that are mechanically driven into the soil (e.g. Stone \& Phan, 1995; Stone \& Kyambadde, 2007).

Hansbo (1957) presented equation (6) which is used to derive undrained shear strength values from the fall cone test:

$$
c_{u}=K \frac{m g}{d^{2}}
$$

If we consider the British Standard test, the liquid limit occurs when an 80 gram cone penetrates by $20 \mathrm{~mm}$. If we assume that this corresponds to a strength of $1.7 \mathrm{kPa}$, a $K$ value of 0.867 results. The values of strength predicted using $K$ equal to 0.867 are as reliable as this assumed strength at liquid limit. The liquid limits obtained from the Casagrande cup and the British Standard fall cone test will not necessarily coincide owing to the different physical parameter being measured. In this paper liquid limit is determined only using the British Standard fall cone test for all the clays studied. The undrained shear strengths that result from using equation (6) are remoulded soil strengths and do not account for soil structure, fabric and overconsolidation level in the way that triaxial or direct simple shear testing can.

\subsection{Rate effects in the fall-cone test}

As different testing methods such as the laboratory vane or tri-axial testing impose different deformation mechanisms and strain rates on the soil sample, this will result in different strengths being measured using differing methods. The strength data analysed in this paper were hence taken only from fall-cone testing using a British Standard cone, in order to ensure that differences between testing methods did not distort the data.

Despite the data analysed in this paper being derived solely from standard fall-cone testing, there is still a potential rate effect in the data owing to the differing penetrations of the fall-cone at different soil strengths. 
In order to quantify this effect, the variation of fall-cone velocity must be investigated. If we assume equation 6 to hold with a constant cone factor, it can be shown that the equation of motion for the cone is:

$$
m a=m v \frac{d v}{d s}=m g-\frac{c_{u} s^{2}}{K}
$$

Integrating equation (7) gives:

$$
v^{2}=2\left[g s-\frac{c_{u} s^{3}}{3 K m}\right]
$$

The maximum value of this velocity can be shown to be:

$$
v_{\text {max }}=\sqrt[4]{\frac{16 g^{3} m K}{9 c_{u}}}=\sqrt[2]{\frac{4 g d}{3 \sqrt{3}}}
$$

As the maximum velocity is hence inversely proportional to the fourth root of the soil strength, $c_{u}$, the effect of this on the data presented here can be quantified. If in the plastic range, the soil strength was expected according to equation (2), to vary by a factor of approximately 100 , the maximum velocity might hence vary by a factor of around 3 .

Ladd \& Foott (1974) based on a synthesis of data published prior to that time stated that strength increases with strain rate at $10 \pm 5$ per cent per log-cycle for tri-axial compression tests. Kulhawy \& Mayne (1990) processed data collected from sixteen publications and showed statistically that the ten per cent increase per log-cycle could be justified based on data of 26 clays tested in triaxial compression. This relationship can be written in the dimensionless form shown in equation (10):

$$
\frac{c_{u}}{c_{u, \text { ref }}}=1.0+0.10 \log _{10}\left(\frac{\dot{\varepsilon}}{\dot{\varepsilon}_{\text {ref }}}\right) \quad R^{2}=0.802, n=209
$$

Koumoto \& Houlsby (2001) processed the test data from Berre \& Bjerrum (1973), Vaid \& Campanella (1977) and Lefebvre \& Leboeuf (1987) formulated an equation functionally equivalent to equation (10).

Assuming a strength increase of ten per cent per log cycle, (equation 10), we might expect to see a five per cent greater enhancement of strength measured at the liquid limit due to strain rate effects than would be observed at the plastic limit. This five per cent variation is insignificant within the scope of this paper.

\section{DATABASE OF FALL CONE TESTS}

Given that neither the log-log nor the conventional log-linear relationships between liquidity index and penetration depth (or $c_{u}$ ) have a theoretical basis, the most appropriate way to evaluate these approaches is via a statistical analysis of a large database of results. Fall cone data on a variety of soils were collected from 
published literature. The sources of the data analysed are summarised in Table 2. The vast majority of the soils in the database are reconstituted soils from natural deposits. Some authors also reported data of commercially produced kaolin and bentonite - these have also been included in the database. The following criteria were set when sourcing data for inclusion in the database:

1. The fall cone readings must be taken using the standard British cone ( 80 gram, $30^{\circ}$ cone angle). Plastic limit from the thread rolling test must be available so that liquidity index can be calculated

2. Fall cone readings must be available for water contents on both sides of liquid limit so that $w_{L}$ can be accurately calculated (at a cone penetration of $20 \mathrm{~mm}$ )

3. In order to exclude potentially brittle samples, fall cone results were excluded that had a water content less than plastic limit plus three per cent, as this is the reported repeatability of the thread rolling test (Sherwood, 1970). Brittleness of dry samples subjected to fall cone testing may lead to exaggerated penetration distances being recorded, equation (6) only being valid for ductile materials. This can be observed in the data of Campbell (1976) who showed dramatically increasing penetration distances for soils at water contents below plastic limit.

Some data were excluded from the database owing to their violation of the conditions set above, the details of these exclusions being outlined in Table 2. The resulting database for analysis contains 641 fall cone measurements on 101 soils from 12 countries. It should be noted that around half of the database is from one source (Kyambadde, 2010). While there is a possible systematic bias in plastic limit readings of up to plus or minus three per cent due to operator sensitivity (Sherwood, 1970), the overall trends described later in the paper hold with or without inclusion of this half of the database. It was hence concluded that no significant bias was introduced by this significant dependence on a single source of data. It is worth noting that the plus or minus three per cent uncertainty in water content at plastic limit can have a significant effect on calculation of liquidity index for soils with low $I_{p}$ close to the plastic limit. However, due to the size of the database presented in this paper, this should not significantly impact on the correlations derived.

Figure 3 shows the database soils (with the exception of three very high plasticity bentonitic soils) plotted on the Casagrande chart. None of the soils plot above the U-line (Howard, 1984) which indicates that the dataset conforms to the general correlation framework proposed by Casagrande (1947). 


\section{STATISTICAL ANALYSIS}

When performing regression analysis, simply quoting $R^{2}$ does not give sufficient information to determine the validity of the correlation (e.g. Kulhawy \& Mayne, 1990). In addition to the scatter-plots showing the correlation to the original data, the following pertinent statistical measures quoted for the analyses presented in this paper are defined below and unless otherwise stated the definitions and notation are consistent with those presented in Montgomery et al (2004):

- Correlation coefficient, $r$

- Coefficient of determination, $R^{2}$

- Number of data points used in the regression, $n$

- The smallest level of significance that would lead to the rejection of the null hypothesis, i.e. that the value of $r=0$, in the case of determining the $p$-value for a regression, $p$

- Standard Error, $S E$

- Relative Deviation, $R D$.

The coefficient of determination, $R^{2}$ is calculated using equation (11):

$$
R^{2}=1-\frac{S S_{E}}{S S_{T}}
$$

Where,

$$
\begin{aligned}
& S S_{E}=\sum_{i=1}^{n} e_{i}^{2} \\
& e_{i}=\mathrm{i}^{\text {th }} \text { calculated error between the observed and predicted } y \text {-value; }
\end{aligned}
$$

$$
S S_{T}=\sum_{i=1}^{n} y_{i}^{2}-\frac{\left(\sum_{i=1}^{n} y_{i}\right)^{2}}{n} \quad y_{i}=\mathrm{i}^{\text {th }} \text { observed } \mathrm{y} \text {-value (response variable) }
$$

In percentage terms, $\left(100 R^{2}\right)$ is the percentage of variability explained by the model. For example, a regression with $R^{2}$ of 0.4 can be interpreted as explaining $40 \%$ of the variability in the data.

The number of data points $(n)$ is essential for testing the quality of the regression. This quantity is quoted as it is linked to the $p$-value which is the probability that the null hypothesis (no correlation) applies. The more data points there are in a regression, the lower is the $R^{2}$ needed to have a high probability of correlation. The $p$-values quoted are taken from Paradine \& Rivett (1953, p.276). For example, a regression with 20 data points (18 degrees of freedom, two-sided tests assumed) and an $R^{2}$ of 0.68 , a $p$-value of 0.001 is calculated. This means that there is a 1 in 1000 chance that no correlation exists. Importantly, this does not mean that there is a 99.9 per cent chance that the trend line drawn is valid, just that there is a correlation between the two variables. 
The standard error, or sample standard deviation, is a measure of the error in the prediction of $y$ for an individual $x$ and is calculated by equation (14):

$$
S E=\left(\frac{S S_{E}}{(n-2)}\right)^{0.5}
$$

Finally, the relative deviation (Waters \& Vardanega, 2009) is essentially the ratio of the deviations about the fitted line to the deviations about the mean y-line and is given by equation (15):

$$
R D=100\left(1-R^{2}\right)^{0.5}
$$

The relative deviation is a more sensitive parameter when the scatter about the fitted line is smaller. It is most useful when comparing relationships with high $R^{2}$ values, as is the case in the analysis presented here.

\section{STRENGTH VARIATION (INDIVIDUAL SOILS)}

The traditional model used to interpret fall-cone data, hereafter referred to as the semi-logarithmic model is given by:

$$
\ln \left(c_{u}\right)=S-H w
$$

Equation (17) shows that the quantity $H$ (from equation 16) is directly linked to the value of $R_{M W}$ in equation (3) via the plasticity index:

$$
R_{M W}=e^{H\left(I_{P}\right)}
$$

Kodikara et al (1986), (2006), Feng (2000), (2001) and Koumoto \& Houlsby (2001) proposed the use of a double logarithmic model to describe fall cone data, hereafter referred to as the power model, given by:

$$
\ln \left(c_{u}\right)=S^{*}-H^{*} \ln (w)
$$

Shimobe (2010), with the aim of predicting plastic limit from fall cone testing, analysed a large database of results and also adopted the power model.

Using a large database we can study whether one model has superior predictive capacity to the other. Table 3 summarises the model parameters and statistical measures that result from fitting equation (16) and equation (18) to the fall cone versus water content data for the 101 soils in the database.

Examination of the data in Table 3 shows that of the 101 soils in the database, 16 show superior coefficients of determination and relative deviation values when the semi-logarithmic model is fitted to the data. In the remaining cases the best model for predictive capacity is the power model. The mean error for the semi-logarithmic model was calculated to be 10.01 per cent on $c_{u}$ with a standard deviation of 9.36. This 
reduces to 7.72 per cent on $c_{u}$ with a standard deviation of 7.16 for the power model. While it is clear that the power model is superior statistically it does not present a hugely significant practical improvement.

Typically, fall-cone tests would be conducted when measuring the liquid limit of a soil, and it would be attractive to be able to use these data to predict strengths in the plastic range. Extrapolation using the results from a liquid limit test should be performed with extreme caution. BS1377 suggests that the liquid limit be determined from penetrations in the range $15-25 \mathrm{~mm}$. Extrapolating using the data in this range to strengths closer to the plastic limit can produce large errors, regardless of which model is used to describe the variation of strength with water content.

\section{STRENGTH VARIATION (ENTIRE DATABASE)}

\subsection{Semi-logarithmic relationship}

It is possible that the improvement when using the power model as opposed to the traditional semilogarithmic model for individual soil test data is not as marked when analysing the entire database. The semi-logarithmic relationship (equation 5) used in the seminal paper Worth \& Wood (1978) relates liquidity index to the undrained shear strength directly via:

$$
c_{u}=c_{L} R_{M W}^{\left(1-I_{L}\right)}
$$

Regressions are constructed by plotting liquidity index against the logarithm of undrained shear strength for the entire dataset. Figure 4 shows such a regression for the 101 soils in the database. Figure 5 shows the accompanying predicted versus measured plot.

The resulting regression equation is:

$$
\begin{aligned}
& I_{L}=1.150-0.283 \ln \left(c_{u}\right) \quad \mathrm{kPa} \\
& R^{2}=0.948, n=641, S E=0.059, R D=22.9 \%, p<0.001
\end{aligned}
$$

The regression line (equation 19) was adjusted such that it passes through $c_{u}$ equal to $1.7 \mathrm{kPa}$ at liquid limit: this did not reduce the coefficient of determination by any significant amount (the adjustment affected the third decimal place of the $R^{2}$ value). Rearranging (as shown in the Appendix) to the form shown in equation (5) we get:

$$
c_{u}=\left(c_{L}\right) 34.3^{\left(1-I_{L}\right)} \approx\left(c_{L}\right) 35^{\left(1-I_{L}\right)}
$$


Since the $R_{M W}$ value yielded by the best-fit regression for database is around 35, the slope implied by the assumption an 100-fold strength increase between liquid and plastic limit appears unconservative (by almost a factor of 3).

The correlations shown in this paper are also supported by another published database. Noting that equation (16) can be re-arranged to give:

$$
H=\frac{\partial \ln \left(c_{u}\right)}{\partial w}
$$

From equation (20) it can be shown that:

$$
\frac{\partial \ln \left(c_{u}\right)}{\partial w}=\frac{-\ln (34.3)}{w_{L}-w_{p}}=\frac{-3.54}{I_{p}}=H
$$

Interestingly, Sridharan et al (1999) correlated the plasticity index with the slopes of liquid limit test data and observed that for a database of mainly Indian clays:

$$
I_{P}=0.75 \frac{\delta \mathrm{w}}{\delta \log _{10} \mathrm{~d}}
$$

Equivalent to:

$$
I_{P}=0.75 \frac{\delta \mathrm{w}}{\delta \frac{\ln (\mathrm{d})}{\ln (10)}}
$$

As $c_{u}$ is proportional to penetration depth $d$ squared, this can be rearranged to give:

$$
I_{P}=-1.5 \ln (10) \frac{\delta \mathrm{w}}{\delta \ln \left(\mathrm{c}_{\mathrm{u}}\right)}=-3.45 \mathrm{H}
$$

The close agreement between the factor 3.54 in equation (22) and 3.45 in equation (25) gives further evidence for this trend of changing strength with water content, beyond that seen in the database presented here.

An $R_{M W}$ value of 35 would imply a strength at plastic limit of around $60 \mathrm{kPa}$ - although the plastic limit test itself is not a measure of strength (Haigh et al 2013). The plastic limit does not occur at a fixed shear strength, being solely the onset of brittleness, so a range of results is observed. In the database presented in Haigh et al (2013) the median strength at plastic limit was reported to be $132 \mathrm{kPa}$ with a mean value of 152 $\mathrm{kPa}$ and a standard deviation of $89 \mathrm{kPa}$. This corresponds to a mean increase of strength by a factor 89 between liquid and plastic limits. This value is greater than that given by equation 20), as the strength at water contents close to plastic limit exceeds that predicted by the equation. Equation (20) is hence not valid at liquidity indices below 0.2 where few data-points are present. There is also considerable curvature in the 
data at $I_{L}$ values above around 1.1 and therefore it is also suggested that equation (20) not be used at high values of $I_{L}$.

$$
c_{u}=c_{L} 35^{\left(1-I_{L}\right)} \quad \mathrm{kPa} \quad 0.2<I_{L}<1.1 \quad \text { (20) bis }
$$

\subsection{Logarithmic Liquidity Index}

Before adopting a semi-logarithmic model to describe a general equation linking undrained shear strength and liquidity index, it is also acknowledged that the analysis in the previous section did favour a power model when considering data of individual soils. Examination of the database shows that there is some curvature in the data when it is plotted on linear axes, so a log-log relationship should also be investigated. However, a log-log plot of liquidity index and undrained strength will inevitably run into difficulty as the plastic limit is approached since $\log 0 \rightarrow-\infty$. Koumoto \& Houlsby (2001) explain that if a power model is to be used then a 'logarithmic liquidity index' needs to be defined.

From Figure 6 it can be shown that:

$$
\ln \left(\frac{c_{u}}{c_{u, L L}}\right)=\left[1-\frac{\ln \left({ }^{w} / w_{p}\right)}{\ln \left({ }^{w_{L} / w_{p}}\right)}\right] \ln \left({ }^{c_{u, P L}} / c_{u, L L}\right)
$$

Therefore, using the definition of logarithmic liquidity index from Koumoto \& Houlsby (2001):

$$
I_{L N}=\frac{\ln \left(w^{w} / w_{p}\right)}{\ln \left({ }^{w_{L}} / w_{p}\right)}
$$

Figure 7 shows a plot of the logarithm of undrained shear strength plotted against the logarithmic liquidity index. The following best fit regression equation is determined:

$$
\begin{aligned}
& I_{L N}=1.120-0.226 \ln \left(c_{u}\right) \\
& R^{2}=0.949, n=641, S E=0.046, R D=22.6 \%, p<0.001
\end{aligned}
$$

As with equation (19), the above equation was adjusted such that $c_{u}$ at liquid limit is equal to $1.7 \mathrm{kPa}$. Equation (27) is very similar to the 'theoretical' equation proposed by Koumoto \& Houlsby (2001) when advocating use of a 60 gram 60 degree cone as standard and a factor 100 strength increase from liquid to plastic limit. They commented that the equation fit the data of the six clays shown on Figure 2 reasonably well $^{1}$ :

$$
I_{L N}=1.070-0.217 \ln \left(c_{u}\right)
$$

Rearranging equation (27) to a form analogous to that shown in equation (5) we get:

\footnotetext{
${ }^{1}$ Equation 28 from implies a strength at liquid limit of $1.38 \mathrm{kPa}$ as it pertains to the use of a $60 \mathrm{~g} 60^{\circ}$ cone 


$$
c_{u}=\left(c_{L}\right) 83.5^{\left(1-I_{L N}\right)} \quad \mathrm{kPa}
$$

Figure 8 shows the predicted versus measured plot for the whole database using equation (30). As with the semi-logarithmic model most of the data fits within the bandwidth \pm 50 per cent. A reduction in scatter at low values of $c_{u}$ is apparent with use of the logarithmic liquidity index to predict values of undrained shear strength (cf. Figure 5 and 8).

\subsection{Effect of mineralogy}

Muir Wood (1990) postulated that $R_{M W}$ depends on the activity of the clay mineral present. This suggestion was based on analysis of data from Dumbleton \& West (1970) where the kaolinite mixtures showed an $R_{M W}$ value close to 30 and the montmorillonitic mixtures showed an $R_{M W}$ value closer to 100 . Analysis of the computed $R_{M W}$ values in Table 3 reveals that the bentonitic (montmorillonitic) soils have $R_{M W}$ values in the range of 15 to 20. Only two soils (a Weald clay and a London clay sample) have $R_{M W}$ values above 100 . Table 4 shows the statistical spread of the $R_{M W}$ values in the database when divided amongst the soil classification categories shown on Figure 2. Apart from the MI and ML categories (which have few datapoints) the range of the average $R_{M W}$ values is from (21.3 to 39.3). There is some spread between classifications e.g. the CE category is dominated by Bentonitic soils which seem to have a slightly lower $R_{M W}$ value. Nonetheless the differences may be statistical only. None of the categories have a mean value that approaches the commonly assumed value of 100 . Indeed, a strong mineralogical link to the $R_{M W}$ value is not obvious from analysis of this very large database.

\subsection{Comparison of models}

Figure 9 shows the variation of strength with liquidity index data for the entire database. The $R_{M W}=35$ line realistically describes this dataset in the suggested range $0.2<I_{L}<1.1$. To compare this model with the logarithmic liquidity index formulation (equation 27) the following analysis is performed. Substituting equation (27) into equation (28) we get:

$$
I_{L N}=\frac{\ln \left(\frac{w}{w_{p}}\right)}{\ln \left(\frac{w_{L}}{w_{p}}\right)}=a-b \ln \left(c_{u}\right)
$$

Where, based on the analysis of the database,

$$
a=1.120 \text { and } b=0.226
$$




$$
\begin{aligned}
& \ln \left(\frac{w}{w_{p}}\right)=\ln (\alpha)\left[a-b \ln \left(c_{u}\right)\right] \quad \text { where, } \alpha=\frac{\mathrm{w}_{\mathrm{L}}}{\mathrm{w}_{\mathrm{p}}} \\
& \frac{w}{w_{p}}=\alpha^{a} \alpha^{-b \ln \left(c_{u}\right)} \\
& I_{L}=\frac{w-w_{p}}{w_{L}-w_{p}}=\frac{w_{p}}{w_{L}-w_{p}}\left[\left(\alpha^{\left.\left.-b \ln \left(c_{u}\right) \alpha^{a}\right)-1\right]}\right.\right. \\
& I_{L}=\frac{\left[\left(\alpha^{\left.\left.-b \ln \left(c_{u}\right) \alpha^{a}\right)-1\right]}\right.\right.}{(\alpha-1)}
\end{aligned}
$$

The minimum value of $\alpha$ in the database is 1.21, the average value being around 2.4. On Figure 9, equation (35) is plotted with varying values of $\alpha(1.9,2.4$ and 2.9), those representing the mean value and one standard deviation above and below the mean. The curvature of the data at the extremes of the dataset is better accommodated using equation 35 with $\alpha=2.4$ (the average of the soils in the database). Having said this, when attempting to relate $I_{L}$ to $c_{u}$ in the range $0.2<I_{L}<1.1$ the predictions are not greatly improved by using the logarithmic liquidity index and in this range equations (20 and 30) are functionally equivalent.

\section{CONCLUSIONS}

A database of 641 fall cone measurements of 101 soil samples has been presented and analysed to study the variation of fall-cone undrained shear strength with liquidity index. In summary:

(a) The commonly used semi-logarithmic relationship between strength and liquidity index invoking a 100fold strength increase between liquid and plastic limit has been shown to be unduly high, with a ratio 35 being a superior fit to a large database of results. A modified equation based on that given by Wroth \& Wood (1978) and Wood (1990), is proposed that represents a superior fit to the collected data:

$$
c_{u}=c_{L} 35^{\left(1-I_{L}\right)} \quad\left(\text { where, } c_{L}=1.7 \mathrm{kPa}\right) \quad 0.2<I_{L}<1.1 \quad \text { (20) bis }
$$

This equation is supported independently by the database of Sridharan et al (1999).

(b) While it was postulated by Wood (1990) that $R_{M W}$ might be a function of soil mineralogy (being greater for montmorillonitic soils than for kalonitic ones): analysis of this large dataset did not reveal this trend.

(c) The power model to describe the variation of fall cone shear strength and water content suggested in Kodikara et al (1986, 2006); Feng $(2000,2001)$ and Koumoto \& Houlsby (2001) presents a marginal statistical improvement over the conventional semi-logarithmic approach when fitting data for a particular 
soil. After examining the results of individual soils in the database it is clear that statistically a power-law fitting is preferred in the majority of individual soils.

(d) Use of a logarithmic liquidity index as defined in Koumoto \& Houlsby (2001) (equation 27) and the resulting regression equation (28) has been shown to account for the curvature at the extreme parts of the dataset but only a marginal statistical improvement over equation 20 .

$$
c_{u}=\left(c_{L}\right) 83.5^{\left(1-I_{L N}\right)} \mathrm{kPa} \quad\left(\text { where, } c_{L}=1.7 \mathrm{kPa}\right) \quad \text { (30) bis }
$$

(e) Equations (20) and (30) are derived from analysis of a large database of fall cone test results and are functionally similar in the range $0.2<I_{L}<1.1$. Both of the equations offer a much better statistical fit to the database than the Wroth \& Wood (1978) formulation in the range $0.2<I_{L}<1.1$.

\section{APPENDIX}

Equation (19) has the form:

$$
I_{L}=a-b \ln \left(c_{u}\right)
$$

Therefore,

$$
\begin{aligned}
& I_{L}-1=a-b \ln \left(c_{u}\right)-1 \\
& \frac{1-I_{L}}{b}=-\frac{a}{b}+\ln \left(c_{u}\right)+\frac{1}{b} \\
& \ln \left(c_{u}\right)=\left(\frac{a}{b}-\frac{b}{a}\right)+\frac{1}{b}\left(1-I_{L}\right) \\
& c_{u}=e^{\left(\frac{a-1}{b}\right)} e^{\left(\frac{1}{b}\right)\left(1-I_{L}\right)}
\end{aligned}
$$

Equation (40) has the same form as equation (5) where,

$$
\begin{aligned}
& c_{L}=e^{\left(\frac{a-1}{b}\right)} \\
& R_{M W}=e^{\left(\frac{1}{b}\right)}
\end{aligned}
$$

The algebra to transform equation (28) to equation (30) has the same form. 


\section{LIST OF SYMBOLS}

\section{Roman}

a a regression constant

$b \quad$ a regression constant

$c_{L} \quad$ strength of soil at liquid limit (taken as $1.7 \mathrm{kPa}$ in this paper)

$c_{u} \quad$ fall-cone undrained shear strength

$c_{u, L L} \quad$ fall-cone undrained shear strength at the liquid limit

$c_{u, P L} \quad$ fall-cone undrained shear strength at the plastic limit

$c_{u, r e f} \quad$ a reference shear strength

$d \quad$ final fall-cone penetration

$g \quad$ acceleration due to gravity

$H \quad$ slope of fitted linear regression line of $\ln \left(c_{u}\right)$ versus $w$ data

$H^{*} \quad$ slope of fitted linear regression line of $\ln \left(c_{u}\right)$ versus $\ln (w)$ data

$I_{L} \quad$ liquidity index

$I_{L N} \quad$ logarithmic liquidity index

$I_{p} \quad$ plasticity index $\left(w_{L}-w_{P}\right)$

K cone factor

$m \quad$ fall cone mass

w soil water content

$w_{L} \quad$ liquid limit

$w_{p} \quad$ plastic limit determined from the thread rolling test

$R_{M W} \quad$ the ratio of strengths at the liquid and plastic limit

$s \quad$ fall cone penetration at any point in time

$S \quad$ intercept of fitted linear regression line of $\ln \left(c_{u}\right)$ versus $w$ data

$S^{*} \quad$ intercept of fitted linear regression line of $\ln \left(c_{u}\right)$ versus $\ln (w)$ data

$v \quad$ fall cone velocity

\section{Greek}

$\alpha \quad$ ratio of liquid and plastic limit $\left(w_{L} / w_{p}\right)$ 
$\dot{\varepsilon} \quad$ strain rate

$\dot{\varepsilon}_{\text {ref }} \quad$ reference strain rate

\section{Statistical terms}

$r \quad$ correlation coefficient

$R^{2} \quad$ coefficient of determination

$n \quad$ number of data points used to generate a regression

p-value the smallest level of significance that would lead to the rejection of the null

hypothesis, i.e. that the value of $r=0$, in the case of determining the $p$-value for a

regression, $p$

SE $\quad$ standard error of a regression

SD $\quad$ standard deviation

$R D \quad$ relative deviation

$\mathrm{COV} \quad$ coefficient of variation

$y_{i} \quad i^{\text {th }}$ observed y-value (response variable)

\section{ACKNOWLEDGEMENTS}

The authors gratefully acknowledge Dr Kevin Stone of the University of Brighton for providing a copy of the thesis by B. Kyambadde. Thanks to Professor Malcolm Bolton for his helpful comments. Thanks to Dr Sarah Allen for her help with the translation of the Swedish version of Atterberg's original paper. The authors also thank all the reviewers of this paper for their insightful comments and helpful suggestions.

\section{REFERENCES}

Atterberg, A. (1911a) Lerornas forhållande till vatten, deras plasticitetsgränser och plasticitetsgrader. Kungliga Lantbruksakademiens Handlingar och Tidskrift, 50(2): 132-158. (In Swedish)

Atterberg, A. (1911b) Die Plastizität der Tone. Internationale Mitteilungen der Bodenkunde, 1: 4-37 (In German). 
Azadi, M. R. E. and Monfared, S. R. (2012) Fall cone test parameters and their effects on the liquid and plastic limits of homogeneous and non-homogeneous soil samples. Electronic Journal of Geotechnical Engineering, 17K: 1615-1646.

Berre, T. and Bjerrum, L. (1973) Shear strength of normally consolidated clays. Proceedings $8^{\text {th }}$ International Conference on Soil Mechanics and Foundation Engineering, Moscow, 1(1): 39-49.

Bjerrum, L. and Flodin, N. (1960) The Development of Soil Mechanics in Sweden, 1900-1925. Géotechnique, 10(1): 1-18.

British Standard 1377 (1990) Methods of Test for Soils for Civil Engineering Purposes, British Standards Institution, London.

British Standard 5930 (1999) Code of Practice for Site Investigations, British Standards Institution, London.

Campbell, D. J. (1976). Plastic limit determination using a dropcone penetrometer. Soil Science, 27(3): 295300.

CAN/BNQ (1986) Soils - determination of liquid limit by the Swedish fall cone penetrometer method and determination of the plastic limit. Canadian Standards Association and Bureau de normalisation du Québec, CAN/BNQ 2501-092-M-86.

Casagrande, A. (1932) Research on the Atterberg Limits of Soils. Public Roads, 13(8): 121-136.

Casagrande, A. (1947) Classification and identification of soils. Proceedings of the American Society of Civil Engineers, 73(6): 783-810.

Casagrande, A. (1958) Notes of the design of the liquid limit device. Géotechnique, 8(2): 84-91.

Di Matteo, L. (2012) Liquid limit of low to medium-plasticity soils: comparison between Casagrande cup and cone penetrometer test. Bulletin of Engineering Geology and the Environment, 71(1): 79-85.

Dumbelton, M. J. and West, G. (1970) The suction and strength of remoulded soils as affected by composition. Road Research Laboratory Report LR306, Road Research Laboratory, United Kingdom.

Feng, T. (2000) Fall-cone penetration and water content relationship of clays. Géotechnique, 50(2): 181-187.

Feng, T. (2001) A linear $\log \mathrm{d}-\log \mathrm{w}$ model for the determination of consistency limits of soils. Canadian Geotechnical Journal, 38(6): 1335-1342.

Haigh, S. K. (2012) The mechanics of the Casagrande liquid limit test. Canadian Geotechnical Journal, 49(9): 1015-1023. Corrigenda, 49 (9): 1116 and 49 (11): 1329. 
Haigh, S. K., Vardanega, P. J. and Bolton, M. D. (2013) The plastic limit of clays. Géotechnique, 63(6): 435440.

Hansbo, S. (1957) A new approach to the determination of the shear strength of clay by the fall cone test. Swedish Geotechnical Institute Proceedings, 14: 5-47.

Harison, J. A. (1988) Using the BS cone penetrometer for the determination of the plastic limit of soils. Géotechnique, 38(3): 433-438.

Houston, W. N. and Mitchell, J. K. (1969) Property interrelationships in sensitive clays. Journal of the Soil Mechanics and Foundations Division (American Society of Civil Engineers), 95(SM4): 1037-1062.

Howard, A. K. (1984) The Revised ASTM standards on the Unified Classification System. Geotechnical Testing Journal, 7(4): 216-222.

Kodikara, J., Seneviratne, H. N. and Wjyakulasooriya, C. V. (1986). Evaluation of plastic limit and plasticity index by Cone Penetrometer, Proceedings of the Asian Regional Symposium on Geotechnical Problems and Practices in Foundation Engineering, Colombo, Sri Lanka, 1, pp. 117-121.

Kodikara, J., Seneviratne, H., and Wijayakulasooryia, C. (2006). "Discussion of "Using a Small Ring and a Fall-Cone to Determine the Plastic Limit" by Tao-Wei Feng." J. Geotech. Geoenviron. Eng., 132(2): $276-278$.

Koumoto, T. and Houlsby, G. T. (2001) Theory and practice of the fall cone test. Géotechnique, 51(8): 701712.

Kulhawy, F. H. and Mayne, P. W. (1990) Manual on estimating soil properties for foundation design, Rep. No. EL-6800, Electric Power Research Institute, Palo Alto, California.

Kyambadde, B. S. (2010) Soil strength and consistency limits from quasi-static cone tests. Ph.D. Thesis. University of Brighton, United Kingdom.

Kyambadde, B. S and Stone, K. J. L. (2012) Index and strength properties of clay-gravel mixtures. Proceedings of the Institution of Civil Engineers - Geotechnical Engineering, 165(2): 13-21.

Laboratoire Central des Ponts et Chaussées (1966) Détermination rapide des limites d'Atterberg à l'aide d'un pénétromèter et d'un pienomètre d'air. Paris. Dossier SGR/149.

Ladd, C. C. and Foott, R. (1974) A new design procedure for stability of soft clays. Journal of Geotechnical Engineering Division (American Society of Civil Engineers), 100(GT7): 763-786. 
Lawrence, D. M., (1980) Some Properties Associated with Kaolinite Soils. M.Phil. Thesis, University of Cambridge.

Lefebvre, G. and LeBoeuf, D. (1987) Rate effects and cyclic loading of sensitive clays. Journal of Geotechnical Engineering ASCE, 113(5): 476-489.

Leroueil S., Tavenas F. and Bihan J. L. (1983) Propriétés caractéristiques des argiles de l'est du Canada. Canadian Geotechnical Journal, 20(4): 681-705 (In French).

Leroueil, S. and Le Bihan, J. (1996) Liquid limits and fall cones. Canadian Geotechnical Journal, 33(5): 793-798.

Locat, J. and Demers, D. (1988) Viscosity, yield stress, remoulded strength, and liquidity index relationships for sensitive clays. Canadian Geotechnical Journal, 25(4): 799-806.

Montgomery, D. C., Runger, G. C. and Hubele, N. F. (2004) Engineering Statistics (3 ${ }^{\text {rd }}$ Edition). John Wiley and Sons: New York.

Nakase, A., Kamei, T. and Kusakabe, O. (1988) Constitutive parameters estimated by plasticity index. Journal of Geotechnical Engineering (American Society of Civil Engineers), 114(7): 844-858.

Olsson, J. (1921) Metod för undersökning av lerors hållfasthetsegenskaper, tillämpad vid de geotekniska undersökningarna vid Statens Järnvägar (Method for investigating the strength properties of clays, as used in geotechnical investigations by the [Swedish] State Railways). Geologiska Förening, Stockholm, Förhandlingar, 43(5): 502-507.

O'Kelly, B. C. (2013) Atterberg Limits and remoulded shear-strength water content relationship. Geotechnical Testing Journal, 36(6): 1-9.

Paradine, C. G. and Rivett, B. H. (1953) Statistics for Technologists. English Universites Press Ltd: London. Schofield, A. N. and Wroth, C. P. (1968) Critical state soil mechanics. McGraw-Hill: United Kingdom.

Shimobe, S. (2010) Determination of index properties and undrained shear strength of soils using the fallcone test. $7^{\text {th }}$ International Symposium on Lowland Technology, September 16-18, 2010, Saga, Japan.

Sherwood, P. T. (1970) The reproducibility of the results of soil classification and compaction tests. Transport and Road Research Laboratories Report LR 339, Department of Transport, UK.

Sherwood, P. T. and Ryley, M. D. (1970) An investigation of a cone-penetrometer method for the determination of the liquid limit. Géotechnique, 20(2): 203-208. 
Skempton, A. W. (1954) Discussion: Sensitivity of clays and the c/p ratio in normally consolidated clays. Proceedings of the American Society of Civil Engineers, Separate 478: 19-22.

Skempton, A. W. (1957) Discussion: Further data on the $\mathrm{c} / \mathrm{p}$ ratio in normally consolidated clays. Proceedings of the Institution of Civil Engineers, 7: 305-307.

Sridharan, A. Nagaraj, H.B. and Prakash K. (1999) Determination of the plasticity index from flow index. Geotechnical Testing Journal, 22(2): 169-175

Stone, K. J. L. and Phan, K. D. (1995) Cone penetration tests near the plastic limit. Géotechnique, 45(1): $155-158$.

Stone, K. J. L. and Kyambadde, B. S. (2007) Determination of strength and index properties of fine-grained soils using a soil-minipenetrometer. Journal of Geotechnical and Geoenvironmental Engineering (American Society of Civil Engineers), 133(6): 667-673.

Stroud, M. A. (1974) The Standard Penetration test in sensitive clays and soft rocks. In: Proceedings of the European seminar on penetration testing (Stockholm) Vol. 2, Part 2: 366-375.

Vaid, Y. P. and Campanella, R. G. (1977) Time-dependent behaviour of undisturbed clay. Journal of Geotechnical Engineering Division, ASCE, 103(7): 693-709.

Waters, T. J. and Vardanega, P. J. (2009) Re-examination of the coefficient of determination ( ${ }^{2}$ ) using road materials engineering case studies. Road and Transport Research, 18(3): 3-12.

Whyte, I. L. (1982) Soil plasticity and strength: a new approach using extrusion. Ground Engineering, 15(1): $16-24$.

Wood, D. M. (1990) Soil behaviour and critical state soil mechanics. Cambridge University Press: United Kingdom.

Wroth, C. P. (1979) Correlations of some engineering properties of soils. Proceedings, 2nd International Conference on Behaviour of Offshore Structures, Vol. 1, pp. 121-132.

Wroth, C.P. and Wood, D. M. (1978) The correlation of index properties with some basic engineering properties of soils. Canadian Geotechnical Journal, 15(2): 137-145.

Yin, M. (2012) Personal communication.

Zentar, R. and Abriak, N. E. and Dubois, V. (2009) Fall cone test to characterize shear strength of organic sediments. Journal of Geotechnical and Geoenvironmental Engineering (American Society of Civil Engineers), 135(1): 153-157. 


\section{Page 23 of 40}

Zentar, R. and Abriak, N. E. and Dubois, V. (2009) Effects of salts and organic matter on Atterberg limits of dredged marine sediments. Applied Clay Science, 42(3-4): 391-397. 


\section{LIST OF TABLES}

Table 1: Original limits describing soil behaviour from Atterberg (1911a, 1911b)

Table 2: Sources of laboratory fall cone data used in compilation of the database

Table 3: Summary of analysis of the database (fall cone analysis of 101 soils)

Table 4: Mineralogical influence on $R_{M W}$ values

\section{LIST OF FIGURES}

Figure 1: Some liquidity index versus undrained strength relationships

Figure 2: $60^{\circ}$ degree $60 \mathrm{~g}$ fall cone data from Koumoto \& Houlsby (2001) (5 of 6 soil $R_{M W}$ values less than 100)

Figure 3: Soils in the database plotted on the Casagrande chart (chart design adapted from Casagrande, 1947; Howard 1984 and BS 5930, 1999)

Figure 4: Natural logarithm of undrained shear strength plotted against liquidity index: resulting regression shown

Figure 5: Predictive power of semi-logarithmic formulation (equation 20) (key as for Figure 4)

Figure 6: Definition of terms

Figure 7: Natural logarithm of undrained shear strength plotted against logarithmic liquidity index: resulting regression shown

Figure 8: Predictive power of the double logarithmic formulation (equation 30) (key as for Figure 4) Figure 9: Liquidity index plotted against fall cone undrained shear strength with the adopted semilogarithmic model (equation 20) and adopted double logarithmic model (i.e. equation 35 with values of $\alpha=1.9,2.4$ and 2.9 plotted) also shown 
Table 1: Original limits describing soil behaviour from Atterberg (1911a, 1911b)

\begin{tabular}{|c|c|c|}
\hline $\begin{array}{c}\text { Atterberg (1911a) } \\
\text { Swedish }\end{array}$ & $\begin{array}{c}\text { Atterberg (1911b) } \\
\text { German }\end{array}$ & $\begin{array}{c}\text { English interpretation from } \\
\text { Casagrande (1932) }\end{array}$ \\
\hline $\begin{array}{c}\text { öfre } \\
\text { trögflytbarhetsgränsen }\end{array}$ & $\begin{array}{c}\text { Die Grenze der } \\
\text { Schwerflüssigkeit }\end{array}$ & The upper limit of viscous flow \\
\hline vattentäthetsgränsen & Die Grenze der Wässerharte & \\
\hline $\begin{array}{c}\text { nedre } \\
\text { trögflytbarhetsgränsen } \\
\text { (flytgränsen) }\end{array}$ & Die Fließgrenze & $\begin{array}{c}\text { The lower limit of viscous flow } \\
\text { (The liquid limit) }\end{array}$ \\
\hline klibbgränsen & Die Klebegrenze & The sticky limit \\
\hline utrullgränsen & Die Ausrollgrenze & $\begin{array}{l}\text { Rolling limit } \\
\text { (The plastic limit) }\end{array}$ \\
\hline $\begin{array}{c}\text { gränsen för } \\
\text { sammanpackbarhet }\end{array}$ & $\begin{array}{c}\text { Die Grenze des } \\
\text { Zusammenhaftens }\end{array}$ & The cohesion limit \\
\hline krympningsgränsen & Die Schwidungsgrenze & The shrinkage limit \\
\hline
\end{tabular}


Table 2: Sources of laboratory fall cone data used in compilation of the database

\begin{tabular}{|c|c|c|c|}
\hline Publication & Details & Countries & Tests excluded \\
\hline $\begin{array}{l}\text { Sherwood \& Ryley } \\
\text { (1970) }\end{array}$ & $\begin{array}{l}22 \text { British clays } \\
\text { and } 3 \text { Central } \\
\text { African soils }\end{array}$ & $\begin{array}{l}\text { United Kingdom, } \\
\text { Turkey, Sierra } \\
\text { Leone and Ghana }\end{array}$ & $\begin{array}{l}\text { Soils } 8,15,19,20 \text { and } 25 \text { as no } \\
\text { cone penetration values available } \\
\text { in the plastic range i.e. no d } \\
\text { values less than } 20 \mathrm{~mm}\end{array}$ \\
\hline Harison (1988) & 7 Bandung clays & Indonesia & \\
\hline Feng (2000) & $\begin{array}{l}5 \text { fine grained soils } \\
\text { from Asia and } \\
\text { central America }\end{array}$ & $\begin{array}{l}\text { Taiwan and } \\
\text { Panama }\end{array}$ & \\
\hline Zentar et al (2009)a & $\begin{array}{l}5 \text { Dunkirk marine } \\
\text { sediments }\end{array}$ & France & $\begin{array}{l}\text { F12 and F13 removed as } \\
\text { insufficient cone penetration } \\
\text { readings available in the plastic } \\
\text { range }\end{array}$ \\
\hline Zentar et al (2009)b & $\begin{array}{l}10 \text { Dunkirk marine } \\
\text { sediments }\end{array}$ & France & $\begin{array}{l}8 \text { Dunkirk sediments removed as } \\
\text { no cone penetration value } \\
\text { available in the plastic range }\end{array}$ \\
\hline Kyambadde (2010) & $\begin{array}{l}28 \text { tropical soils } \\
26 \text { temperate soils }\end{array}$ & $\begin{array}{l}\text { Uganda and } \\
\text { United Kingdom }\end{array}$ & $\begin{array}{l}\text { S32 and S34 were not included as } \\
\text { no thread-rolling plastic limit } \\
\text { values were available }\end{array}$ \\
\hline $\begin{array}{l}\text { Azadi \& Monfared } \\
(2012)\end{array}$ & 2 silty-clay soils & Azarbaijan & $\begin{array}{l}\text { Only tests using the standard } \\
\text { British cone were included in the } \\
\text { database }\end{array}$ \\
\hline Di Matteo (2012) & $\begin{array}{l}6 \text { alluvial soils } \\
\text { from Paglia }\end{array}$ & Italy & \\
\hline Haigh (2012) & 3 soils & United Kingdom & \\
\hline $\begin{array}{l}\text { Yin (2012) personal } \\
\text { communication }\end{array}$ & 1 marine sediment & Egypt & \\
\hline
\end{tabular}




\section{P綵ge 27 of 40}

Table 3: Summary of analysis of the database (fall cone analysis of 101 soils)

\begin{tabular}{|c|c|c|c|c|c|c|c|c|c|c|c|c|c|c|c|c|c|c|c|}
\hline $\begin{array}{l}\text { Original } \\
\text { publication }\end{array}$ & $\begin{array}{c}\text { Original } \\
\text { source ID }\end{array}$ & Label & $\boldsymbol{w}_{P}$ & $w_{L}$ & $\boldsymbol{R}_{M W}$ & $H$ & $s$ & $R^{2}$ & $n$ & $S E$ & $\begin{array}{l}R D \\
(\%)\end{array}$ & $p$-value & $H^{*}$ & $S^{*}$ & $R^{2}$ & $n$ & $S E$ & $\begin{array}{l}R D \\
(\%)\end{array}$ & $p$-value \\
\hline \multirow[t]{18}{*}{$\begin{array}{l}\text { Sherwood \& } \\
\text { Ryley (1970) }\end{array}$} & 1 & $\begin{array}{l}\text { Kaolinite + 25\% Sulehay } \\
\text { sand }\end{array}$ & 0.17 & 0.262 & 37 & 39.17 & 10.81 & 0.996 & 4 & 0.024 & 6.4 & $0.001<p<0.01$ & 9.86 & -12.65 & 0.996 & 4 & 0.023 & 6.2 & $0.001<p<0.01$ \\
\hline & 2 & Sandy clay (Bagshot) & 0.18 & 0.361 & 44 & 20.92 & 8.07 & 0.995 & 4 & 0.043 & 7.1 & $0.001<p<0.01$ & 7.25 & -6.88 & 0.996 & 4 & 0.036 & 6.0 & $0.001<p<0.01$ \\
\hline & 3 & Sandy clay (Brickearth) & 0.16 & 0.367 & 25 & 15.53 & 6.24 & 0.995 & 4 & 0.038 & 7.0 & $0.001<p<0.01$ & 5.19 & -4.65 & 0.997 & 4 & 0.028 & 5.2 & $0.001<p<0.01$ \\
\hline & 4 & $\begin{array}{l}\text { Sandy clay (Stangate } \\
\text { Hill) }\end{array}$ & 0.17 & 0.399 & 26 & 14.26 & 6.21 & 0.981 & 4 & 0.033 & 13.6 & $0.001<p<0.01$ & 5.90 & -4.89 & 0.984 & 4 & 0.031 & 12.5 & $0.001<p<0.01$ \\
\hline & 5 & Sandy clay (Camberley) & 0.18 & 0.404 & 11 & 10.64 & 4.83 & 0.986 & 6 & 0.061 & 11.7 & $p<0.001$ & 4.36 & -3.45 & 0.994 & 6 & 0.039 & 7.4 & $p<0.001$ \\
\hline & 7 & Silty clay (Middx.) & 0.19 & 0.462 & 45 & 14.03 & 7.01 & 0.996 & 5 & 0.028 & 6.0 & $p<0.001$ & 6.44 & -4.45 & 0.998 & 5 & 0.019 & 4.2 & $p<0.001$ \\
\hline & 9 & Weald clay (Kent) & 0.23 & 0.631 & 16 & 6.95 & 4.92 & 0.992 & 5 & 0.039 & 8.9 & $p<0.001$ & 4.08 & -1.35 & 0.996 & 5 & 0.028 & 6.4 & $p<0.001$ \\
\hline & 10 & Izmir soil & 0.30 & 0.683 & 38 & 9.50 & 7.02 & 0.989 & 4 & 0.058 & 10.5 & $0.001<p<0.01$ & 6.01 & -1.75 & 0.993 & 4 & 0.045 & 8.1 & $0.001<p<0.01$ \\
\hline & 11 & Gault clay & 0.25 & 0.710 & 40 & 8.03 & 6.23 & 0.988 & 5 & 0.051 & 10.9 & $p<0.001$ & 5.52 & $\begin{array}{l}-1.37 \\
\end{array}$ & 0.992 & 5 & 0.043 & 9.1 & $p<0.001$ \\
\hline & 12 & London clay & 0.24 & 0.718 & 17 & 5.95 & 4.80 & 0.987 & 5 & 0.039 & 11.6 & $p<0.001$ & 4.39 & -0.94 & 0.989 & 5 & 0.035 & 10.4 & $p<0.001$ \\
\hline & 13 & Kaolinite & 0.43 & 0.804 & 18 & 7.67 & 6.70 & 0.983 & 6 & 0.055 & 12.9 & $p<0.001$ & 5.78 & -0.72 & 0.986 & 6 & 0.050 & 11.7 & $p<0.001$ \\
\hline & 16 & Wokingham organic clay & 0.43 & 0.870 & 74 & 9.77 & 9.04 & 0.999 & 3 & 0.015 & 3.1 & $p<0.001$ & 8.37 & $\begin{array}{l}-0.63 \\
\end{array}$ & 0.998 & 3 & 0.020 & 4.2 & $0.01<p<0.02$ \\
\hline & 17 & $\begin{array}{l}\text { Hertingfordbury, clayey } \\
\text { sand }\end{array}$ & 0.12 & 0.238 & 25 & 27.26 & 7.01 & 0.996 & 6 & 0.042 & 6.4 & $p<0.001$ & 6.29 & -8.53 & 0.998 & 6 & 0.027 & 4.2 & $p<0.001$ \\
\hline & 18 & Keuper marl & 0.25 & 0.438 & 20 & 15.85 & 7.48 & 0.995 & 4 & 0.031 & 7.2 & $0.001<p<0.01$ & 7.09 & $\begin{array}{l}-5.33 \\
\end{array}$ & 0.996 & 4 & 0.027 & 6.2 & $0.001<p<0.01$ \\
\hline & 21 & Yorkshire clayey silt & 0.28 & 0.421 & 17 & 20.01 & 8.96 & 0.988 & 6 & 0.043 & 11.0 & $p<0.001$ & 8.49 & -6.82 & 0.990 & 6 & 0.040 & 10.2 & $p<0.001$ \\
\hline & 22 & Avonmouth silt & 0.25 & 0.358 & 15 & 25.09 & 9.52 & 0.984 & 3 & 0.108 & 12.7 & $0.05<p<0.1$ & 9.16 & -8.89 & 0.988 & 3 & 0.092 & 10.8 & $0.05<p<0.1$ \\
\hline & 23 & Decomposed granite & 0.14 & 0.250 & 13 & 23.41 & 6.38 & 0.993 & 5 & 0.033 & 8.1 & $p<0.001$ & 5.80 & $\begin{array}{l}-7.53 \\
\end{array}$ & 0.997 & 5 & 0.023 & 5.7 & $p<0.001$ \\
\hline & 24 & Lateritic gravel & 0.14 & 0.272 & 48 & 29.30 & 8.51 & 0.986 & 6 & 0.054 & 11.7 & $p<0.001$ & 7.98 & -9.86 & 0.989 & 6 & 0.049 & 10.5 & $p<0.001$ \\
\hline \multirow{6}{*}{$\begin{array}{l}\text { Harison } \\
\text { (1988) }\end{array}$} & & $\mathrm{CH}$ soil & 0.45 & 1.019 & 50 & 6.89 & 7.56 & 0.983 & 6 & 0.138 & 12.9 & $p<0.001$ & 6.33 & 0.64 & 0.991 & 6 & 0.099 & 9.2 & $p<0.001$ \\
\hline & & Clayey silt & 0.41 & 0.665 & 28 & 13.13 & 9.30 & 0.953 & 6 & 0.288 & 21.7 & $p<0.001$ & 8.02 & -2.74 & 0.973 & 6 & 0.219 & 16.5 & $p<0.001$ \\
\hline & & $\mathrm{OH}$ soil & 0.38 & 0.795 & 39 & 8.80 & 7.54 & 0.989 & 7 & 0.112 & 10.5 & $p<0.001$ & 6.18 & -0.89 & 0.995 & 7 & 0.079 & 7.4 & $p<0.001$ \\
\hline & & Silty clay & 0.42 & 0.896 & 24 & 6.64 & 6.50 & 0.955 & 5 & 0.216 & 21.2 & $0.001<p<0.01$ & 5.46 & $\begin{array}{l}-0.08 \\
\end{array}$ & 0.973 & 5 & 0.168 & 16.5 & $0.001<p<0.01$ \\
\hline & & Silt - low clay fraction (1) & 0.38 & 0.742 & 30 & 9.42 & 7.53 & 0.963 & 4 & 0.236 & 19.3 & $0.01<p<0.02$ & 6.54 & -1.45 & 0.981 & 4 & 0.170 & 13.9 & $0.001<p<0.01$ \\
\hline & & Silt - low clay fraction (2) & 0.39 & 0.641 & 39 & 14.58 & 9.89 & 0.977 & 6 & 0.193 & 15.3 & $p<0.001$ & 8.43 & -3.22 & 0.990 & 6 & 0.126 & 10.0 & $p<0.001$ \\
\hline Feng (2000) & & Taipei clay & 0.24 & 0.418 & 16 & 15.58 & 7.18 & 0.954 & 12 & 0.257 & 21.5 & $p<0.001$ & 5.63 & -4.29 & 0.979 & 12 & 0.174 & 14.5 & $p<0.001$ \\
\hline
\end{tabular}




\section{P 29 of 40}

$\stackrel{D}{D}$

\begin{tabular}{|c|c|c|c|c|c|c|c|c|c|c|c|c|c|c|c|c|c|c|c|}
\hline & S37 & Reddish soil & 0.25 & 0.640 & 27 & 8.48 & 5.97 & 0.981 & 7 & 0.140 & 13.8 & $p<0.001$ & 4.66 & -1.56 & 0.995 & 7 & 0.072 & 7.1 & $p<0.001$ \\
\hline \multirow{14}{*}{$\begin{array}{l}\text { Kyambadde } \\
\text { (2010) British } \\
\text { clays }\end{array}$} & S39 & Kaolin & 0.28 & 0.534 & 18 & 11.45 & 6.66 & 0.991 & 6 & 0.110 & 9.7 & $p<0.001$ & 5.01 & -2.58 & 0.997 & 6 & 0.066 & 5.8 & $p<0.001$ \\
\hline & S47 & Bentonite & 0.51 & 5.525 & 20 & 0.60 & 3.86 & 0.984 & 5 & 0.158 & 12.6 & $p<0.001$ & 2.07 & 4.12 & 0.941 & 5 & 0.307 & 24.4 & $0.001<p<0.01$ \\
\hline & $\mathrm{S} 38$ & Greyish clay & 0.24 & 0.556 & 22 & 9.72 & 5.95 & 0.985 & 5 & 0.122 & 12.4 & $p<0.001$ & 4.84 & -2.33 & 0.992 & 5 & 0.087 & 8.9 & $p<0.001$ \\
\hline & S43 & Brick earth & 0.19 & 0.429 & 44 & 15.80 & 7.33 & 0.971 & 7 & 0.177 & 17.1 & $p<0.001$ & 6.04 & -4.58 & 0.985 & 7 & 0.129 & 12.4 & $p<0.001$ \\
\hline & S51 & Wadhurst clay & 0.27 & 0.467 & 19 & 14.84 & 7.47 & 0.965 & 6 & 0.207 & 18.8 & $p<0.001$ & 6.18 & -4.19 & 0.983 & 6 & 0.142 & 12.9 & $p<0.001$ \\
\hline & S52 & Wealden clay & 0.18 & 0.499 & 42 & 11.70 & 6.38 & 0.992 & 7 & 0.089 & 8.7 & $p<0.001$ & 4.73 & -2.72 & 0.980 & 7 & 0.146 & 14.2 & $p<0.001$ \\
\hline & S55 & Kettering clay & 0.22 & 0.529 & 32 & 11.21 & 6.47 & 0.996 & 6 & 0.059 & 6.1 & $p<0.001$ & 4.85 & -2.51 & 0.992 & 6 & 0.085 & 8.8 & $p<0.001$ \\
\hline & S57 & Brown grey mottled clay & 0.22 & 0.674 & 10 & 5.05 & 3.96 & 0.966 & 4 & 0.153 & 18.4 & $0.01<p<0.02$ & 2.86 & -0.59 & 0.987 & 4 & 0.094 & 11.3 & $0.001<p<0.01$ \\
\hline & $\mathrm{S} 60$ & Bembridge clay & 0.27 & 0.701 & 27 & 7.68 & 5.94 & 0.978 & 7 & 0.175 & 14.8 & $p<0.001$ & 4.26 & -0.95 & 0.984 & 7 & 0.150 & 12.8 & $p<0.001$ \\
\hline & S61 & Silty clay - UK & 0.15 & 0.285 & 23 & 23.15 & 7.14 & 0.959 & 7 & 0.233 & 20.2 & $p<0.001$ & 5.75 & -6.69 & 0.981 & 7 & 0.161 & 14.0 & $p<0.001$ \\
\hline & $\mathrm{S} 62$ & Gault clay & 0.25 & 0.689 & 21 & 6.92 & 5.32 & 0.957 & 6 & 0.173 & 20.8 & $p<0.001$ & 4.21 & -1.04 & 0.962 & 6 & 0.162 & 19.4 & $p<0.001$ \\
\hline & S64 & Gosport clay & 0.17 & 0.490 & 25 & 10.02 & 5.46 & 0.957 & 6 & 0.179 & 20.8 & $p<0.001$ & 4.39 & -2.60 & 0.967 & 6 & 0.157 & 18.3 & $p<0.001$ \\
\hline & $\mathrm{S} 81$ & Peteswood soil sample & 0.27 & 0.952 & 30 & 5.00 & 5.29 & 0.989 & 6 & 0.092 & 10.7 & $p<0.001$ & 4.04 & 0.33 & 0.980 & 6 & 0.120 & 14.0 & $p<0.001$ \\
\hline & 583 & Dark grey sandy clay & 0.22 & 0.532 & 16 & 8.93 & 5.29 & 0.981 & 6 & 0.124 & 13.7 & $p<0.001$ & 4.08 & -2.06 & 0.983 & 6 & 0.117 & 13.0 & $p<0.001$ \\
\hline \multirow{10}{*}{$\begin{array}{l}\text { Kyambadde } \\
\text { (2010) } \\
\text { London clay }\end{array}$} & 567 & Artificial London clay & 0.25 & 0.842 & 37 & 6.10 & 5.66 & 0.998 & 4 & 0.063 & 4.0 & $p<0.001$ & 3.82 & -0.13 & 0.998 & 4 & 0.070 & 4.5 & $p<0.001$ \\
\hline & S68 & London clay & 0.23 & 0.784 & 38 & 6.59 & 5.71 & 0.958 & 6 & 0.186 & 20.6 & $p<0.001$ & 4.29 & -0.50 & 0.936 & 6 & 0.230 & 25.4 & $0.001<p<0.01$ \\
\hline & S70 & LC - Finsbury Park (1) & 0.22 & 0.819 & 94 & 7.59 & 6.76 & 0.981 & 6 & 0.135 & 13.9 & $p<0.001$ & 5.30 & -0.51 & 0.972 & 6 & 0.163 & 16.8 & $p<0.001$ \\
\hline & S71 & LC - Finsbury Park (2) & 0.27 & 0.809 & 21 & 5.62 & 5.11 & 0.931 & 6 & 0.227 & 26.3 & $0.001<p<0.01$ & 4.10 & -0.34 & 0.958 & 6 & 0.178 & 20.6 & $p<0.001$ \\
\hline & S74 & LC - Worcester Park (1) & 0.26 & 0.802 & 30 & 6.27 & 5.57 & 0.992 & 6 & 0.075 & 8.9 & $p<0.001$ & 4.42 & -0.46 & 0.994 & 6 & 0.066 & 7.9 & $p<0.001$ \\
\hline & S75 & LC - Worcester Park (2) & 0.27 & 0.781 & 34 & 6.91 & 5.93 & 0.987 & 6 & 0.088 & 11.2 & $p<0.001$ & 4.85 & -0.68 & 0.986 & 6 & 0.094 & 11.9 & $p<0.001$ \\
\hline & S77 & LC - Streatham & 0.30 & 0.790 & 36 & 7.31 & 6.39 & 0.982 & 7 & 0.143 & 13.4 & $p<0.001$ & 4.85 & -0.53 & 0.995 & 7 & 0.072 & 6.8 & $p<0.001$ \\
\hline & S78 & LC - Rathbone & 0.27 & 0.836 & 22 & 5.46 & 5.15 & 0.898 & 6 & 0.306 & 31.9 & $0.001<p<0.01$ & 4.10 & -0.19 & 0.938 & 6 & 0.238 & 24.8 & $0.001<p<0.01$ \\
\hline & S79 & $\begin{array}{l}\text { London clay - Hampton } \\
\text { (1) }\end{array}$ & 0.20 & 0.465 & 118 & 18.01 & 8.98 & 0.959 & 7 & 0.217 & 20.3 & $p<0.001$ & 7.73 & -5.34 & 0.975 & 7 & 0.171 & 16.0 & $p<0.001$ \\
\hline & $\mathrm{S} 80$ & $\begin{array}{l}\text { London clay - Hampton } \\
\text { (2) }\end{array}$ & 0.23 & 0.692 & 47 & 8.35 & 6.35 & 0.949 & 7 & 0.258 & 22.6 & $p<0.001$ & 4.97 & -1.29 & 0.982 & 7 & 0.031 & 13.5 & $p<0.001$ \\
\hline $\begin{array}{l}\text { Azadi \& } \\
\text { Monfared } \\
\text { (2012) }\end{array}$ & & Clayey silt & 0.24 & 0.285 & 7 & 40.00 & 11.84 & 0.995 & 4 & 0.049 & 6.9 & $0.001<p<0.01$ & $\begin{array}{c}11.5 \\
9\end{array}$ & -14.13 & 0.993 & 4 & 0.061 & 8.6 & $0.001<p<0.01$ \\
\hline \multirow[t]{3}{*}{ Haigh (2012) } & & Kaolin & 0.28 & 0.671 & 34 & 8.92 & 6.56 & 0.963 & 8 & 0.216 & 19.3 & $p<0.001$ & 4.92 & -1.38 & 0.973 & 8 & 0.184 & 16.5 & $p<0.001$ \\
\hline & & Sand-clay mix & 0.12 & 0.226 & 26 & 32.09 & 7.88 & 0.906 & 6 & 0.428 & 30.7 & $0.001<p<0.01$ & 6.57 & -9.20 & 0.941 & 6 & 0.339 & 24.3 & $p<0.001$ \\
\hline & & Bentonite & 0.71 & 1.420 & 15 & 3.82 & 6.00 & 0.995 & 6 & 0.075 & 7.2 & $p<0.001$ & 4.57 & 2.17 & 0.998 & 6 & 0.041 & 3.9 & $p<0.001$ \\
\hline Di Matteo & S1 & Paglia alluvium & 0.24 & 10 & 42 & 22.62 & 9.68 & 0.985 & 12 & 0.045 & 12.4 & $p<0.001$ & 9.08 & -7.70 & 0.987 & 12 & 0.042 & 11.5 & $p<0.001$ \\
\hline
\end{tabular}




\section{Page $\mathbf{3 0}$ of $\mathbf{4 0}$}

\begin{tabular}{|c|c|c|c|c|c|c|c|c|c|c|c|c|c|c|c|c|c|c|c|}
\hline \multirow[t]{5}{*}{ (2012) } & s2 & Paglia alluvium & 0.21 & 0.378 & 17 & 16.86 & 6.91 & 0.980 & 10 & 0.046 & 14.1 & $p<0.001$ & 6.33 & -5.63 & 0.984 & 10 & 0.042 & 12.7 & $p<0.001$ \\
\hline & 53 & Paglia alluvium & 0.20 & 0.353 & 18 & 19.03 & 7.24 & 0.982 & 9 & 0.046 & 13.4 & $p<0.001$ & 6.79 & -6.55 & 0.984 & 9 & 0.045 & 12.8 & $p<0.001$ \\
\hline & S4 & Paglia alluvium & 0.19 & 0.318 & 18 & 22.65 & 7.74 & 0.990 & 10 & 0.041 & 10.2 & $p<0.001$ & 7.15 & -7.67 & 0.989 & 10 & 0.042 & 10.5 & $p<0.001$ \\
\hline & 55 & Paglia alluvium & 0.19 & 0.293 & 14 & 25.53 & 8.02 & 0.987 & 9 & 0.039 & 11.3 & $p<0.001$ & 7.57 & -8.75 & 0.985 & 9 & 0.043 & 12.4 & $p<0.001$ \\
\hline & s6 & Paglia alluvium & 0.18 & 0.271 & 17 & 31.29 & 9.00 & 0.978 & 11 & 0.043 & 15.0 & $p<0.001$ & 8.41 & -10.46 & 0.978 & 9 & 0.043 & 15.0 & $p<0.001$ \\
\hline \multirow[t]{6}{*}{ Yin (2012) } & & WND sediment & 0.44 & 0.911 & 15 & 5.74 & 5.73 & 0.960 & 7 & 0.122 & 20.0 & $p<0.001$ & 5.68 & $\begin{array}{c}-0.03 \\
\end{array}$ & 0.971 & 7 & 0.103 & 16.9 & $p<0.001$ \\
\hline & & Maximum value & 0.71 & 5.53 & 152 & 40.00 & 11.84 & 0.999 & 14 & 0.428 & 31.9 & & 11.5 & 4.13 & 1.000 & 14 & 0.339 & 25.7 & \\
\hline & & Minimum value & 0.12 & 0.23 & 7 & 0.6 & 3.86 & 0.898 & 3 & 0.015 & 3.1 & & 2.07 & -14.13 & 0.934 & 3 & 0.011 & 1.2 & \\
\hline & & Mean value, $\mu$ & 0.25 & 0.65 & 33 & 13.77 & 6.93 & 0.976 & 6.3 & 0.133 & 14.3 & & 5.81 & -3.47 & 0.983 & 6.3 & 0.105 & 11.7 & \\
\hline & & $\begin{array}{l}\text { Number of data points, } \\
n\end{array}$ & 101 & 101 & 101 & 101 & 101 & 101 & 101 & 101 & 101 & & 101 & 101 & 101 & 101 & 101 & 101 & \\
\hline & & Standard deviation, $\sigma$ & 0.11 & 0.64 & 21.6 & 7.89 & 1.55 & 0.021 & 2.0 & 0.08 & 6.2 & & 1.64 & 3.36 & 0.016 & 2.0 & 0.07 & 5.7 & \\
\hline \multicolumn{2}{|c|}{$L C=$ London clay } & $\operatorname{cov} \sigma / \mu$ & 0.42 & 0.97 & 0.65 & 0.57 & 0.22 & 0.021 & 0.3 & 0.63 & 0.43 & & 0.28 & -0.97 & 0.016 & 0.3 & 0.66 & 0.48 & \\
\hline
\end{tabular}


Table 4: Mineralogical influence on $\boldsymbol{R}_{M W}$ values

\begin{tabular}{|c|c|c|c|c|c|c|}
\hline Classification & n & min & max & mean & SD & COV \\
\hline Extremely plastic clays (CE) & 4 & 16.1 & 30.2 & 21.3 & 6.2 & 0.29 \\
\hline Very plastic clays (CV) & 11 & 19.3 & 94.3 & 35.8 & 20.6 & 0.57 \\
\hline High plasticity clays (CH) & 19 & 9.9 & 47.4 & 28.0 & 10.5 & 0.38 \\
\hline Intermediate plasticity clays (CI) & 37 & 10.8 & 152.3 & 39.3 & 28.4 & 0.72 \\
\hline Low plasticity clays (CL) & 13 & 13.1 & 61.7 & 31.6 & 15.8 & 0.50 \\
\hline Extremely plastic silts (ME) & 6 & 10.4 & 55.7 & 26.4 & 20.8 & 0.79 \\
\hline Very plastic silts (MV) & 5 & 17.6 & 73.7 & 36.7 & 22.1 & 0.60 \\
\hline High plasticity silts (MH) & 3 & 28.4 & 38.8 & 32.3 & 5.6 & 0.17 \\
\hline Low plasticity silts (MI) & 2 & 15.0 & 16.8 & 15.9 & 1.3 & 0.08 \\
\hline Low plasticity silts (ML) & 1 & - & - & 7.1 & - & - \\
\hline
\end{tabular}


Figure 1

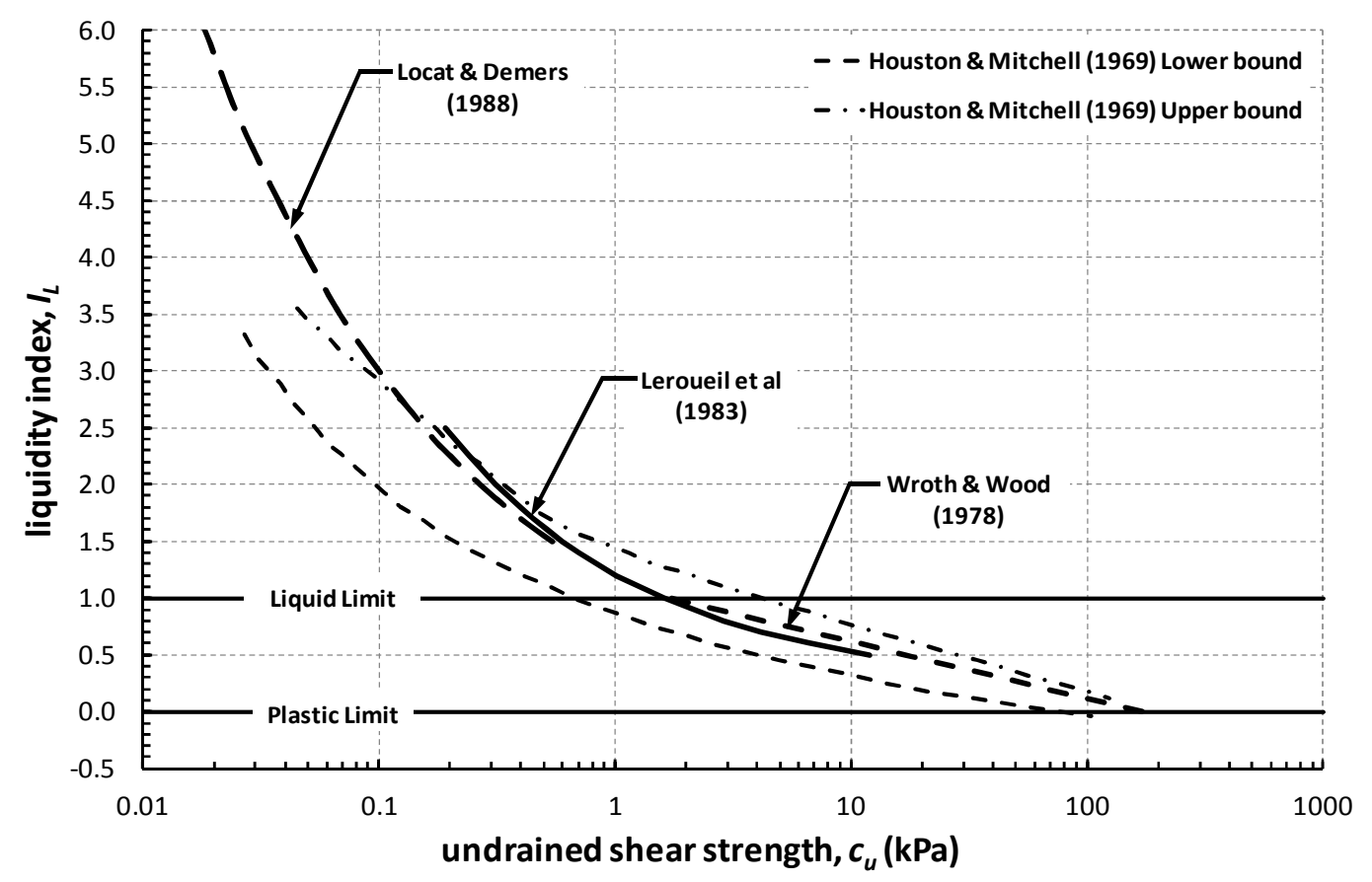


Figure 2

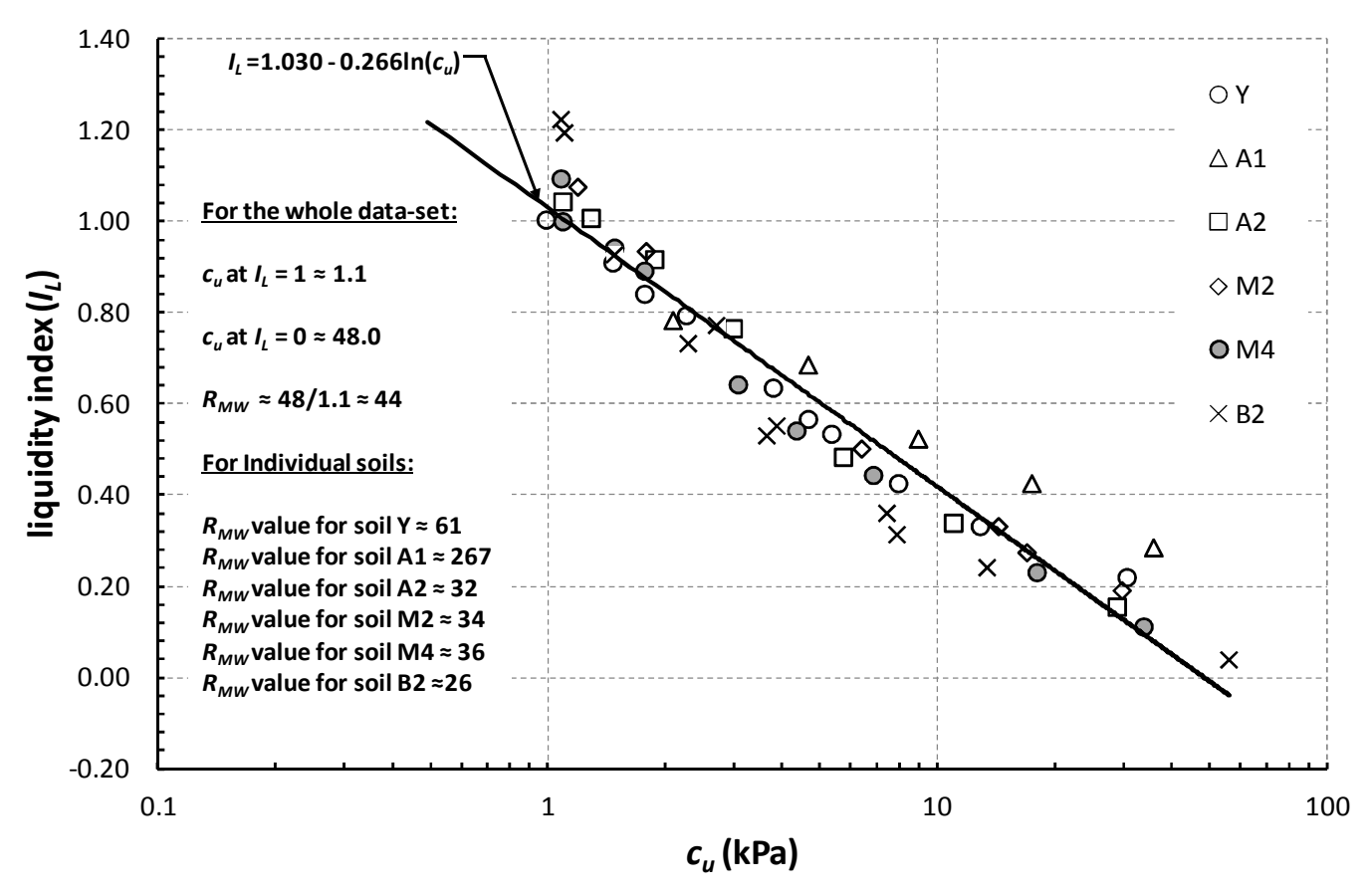


Figure 3

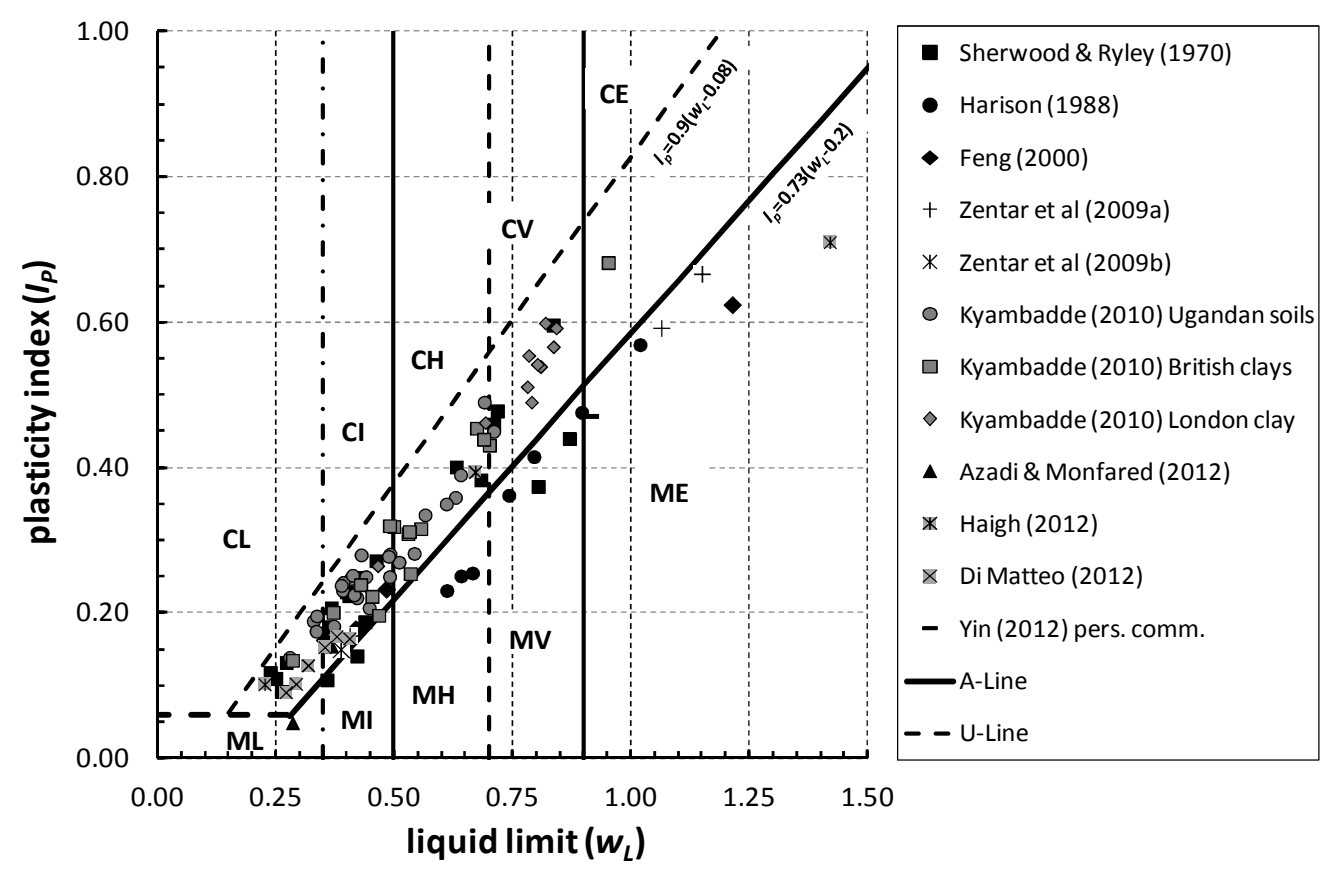


Figure 4

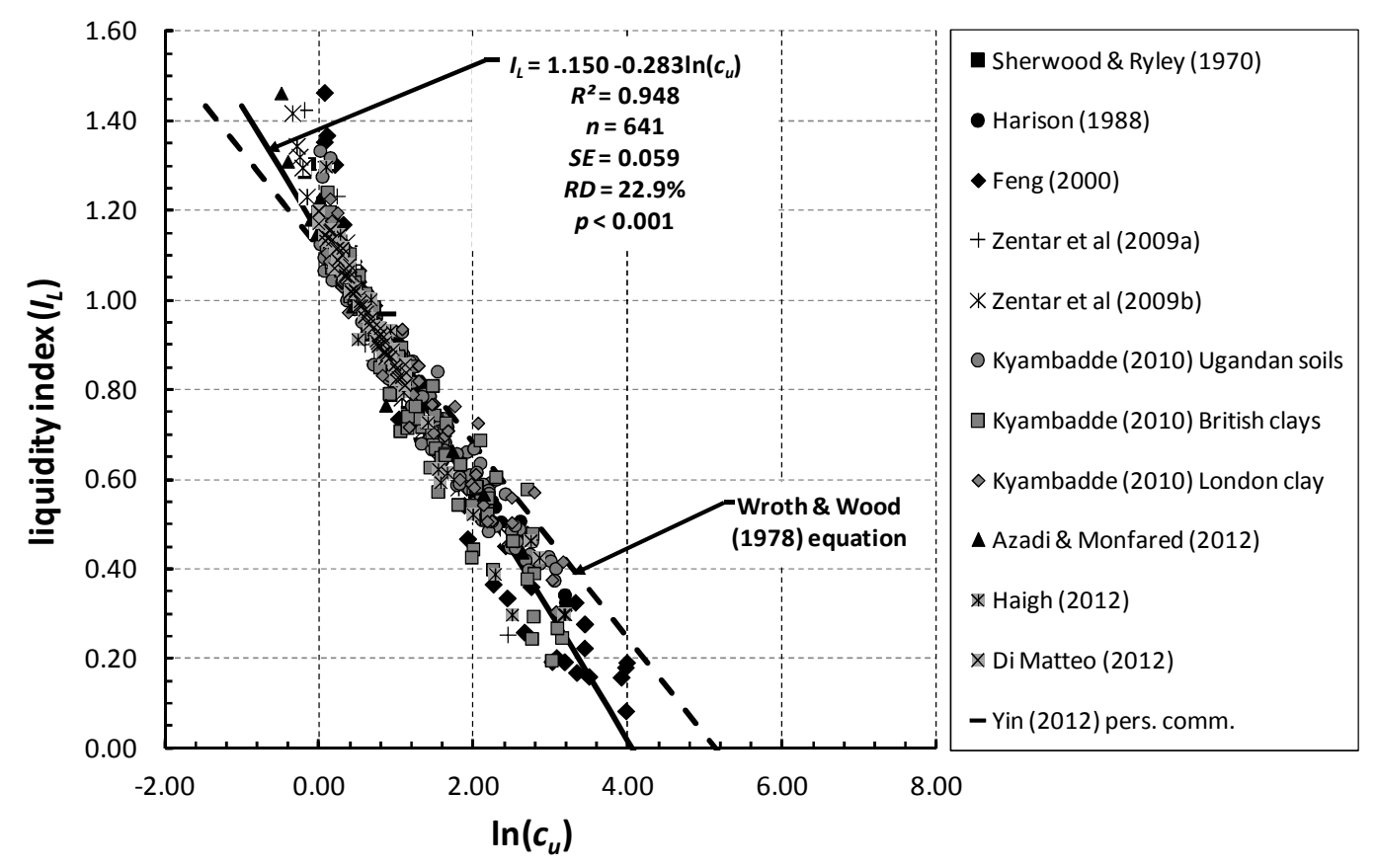


Figure 5

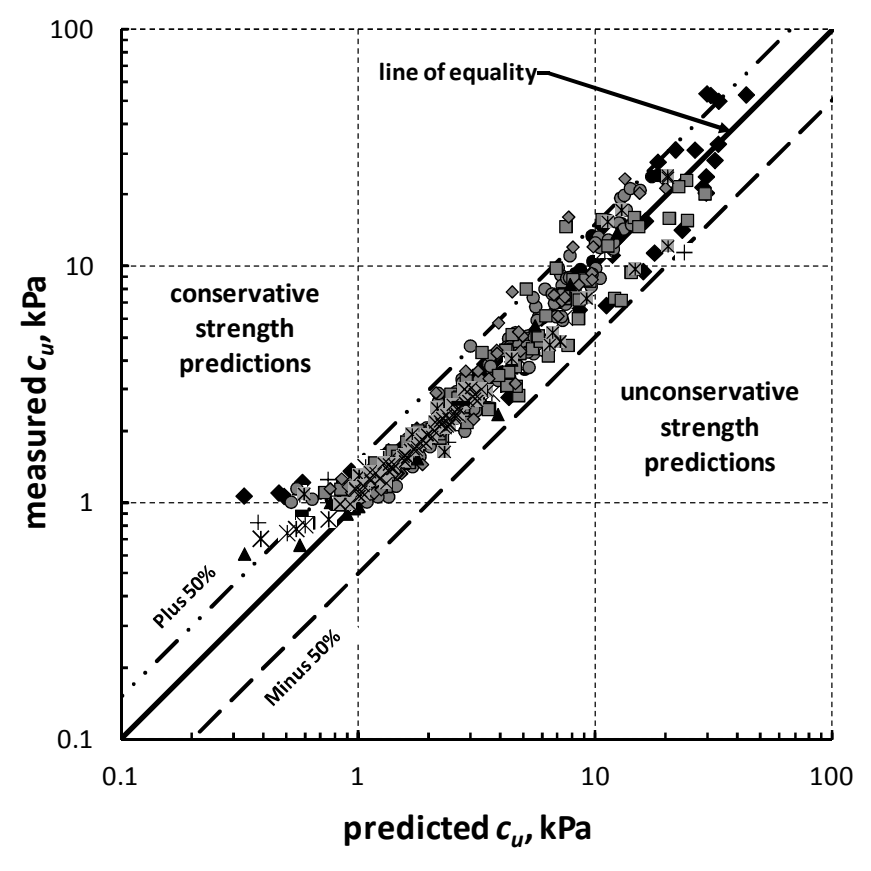


Figure 6

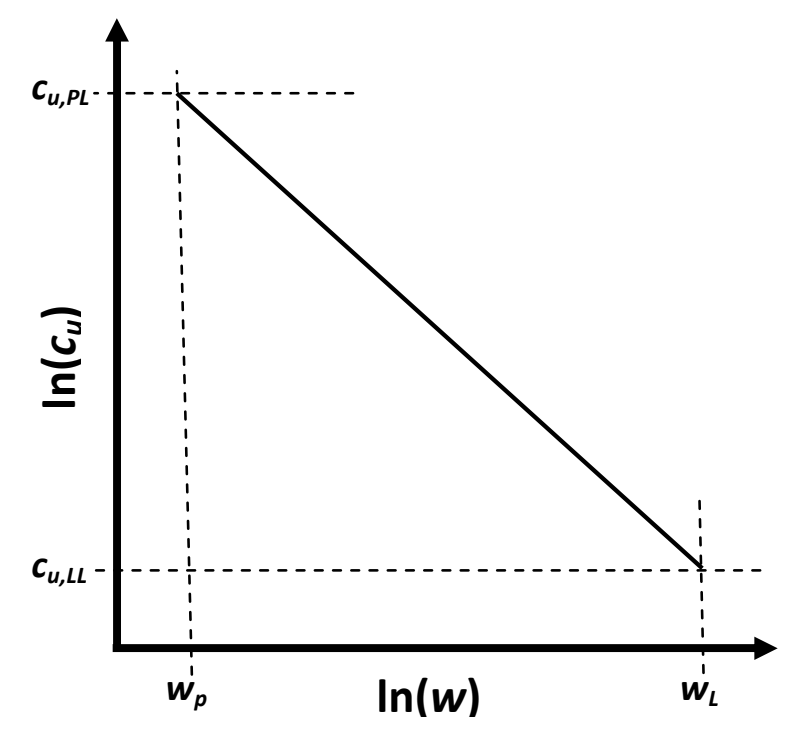

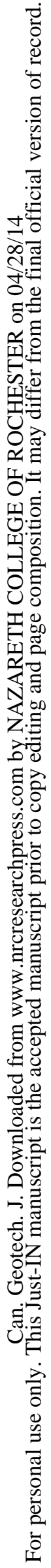 \\ Page 37 of 40}


Figure 7

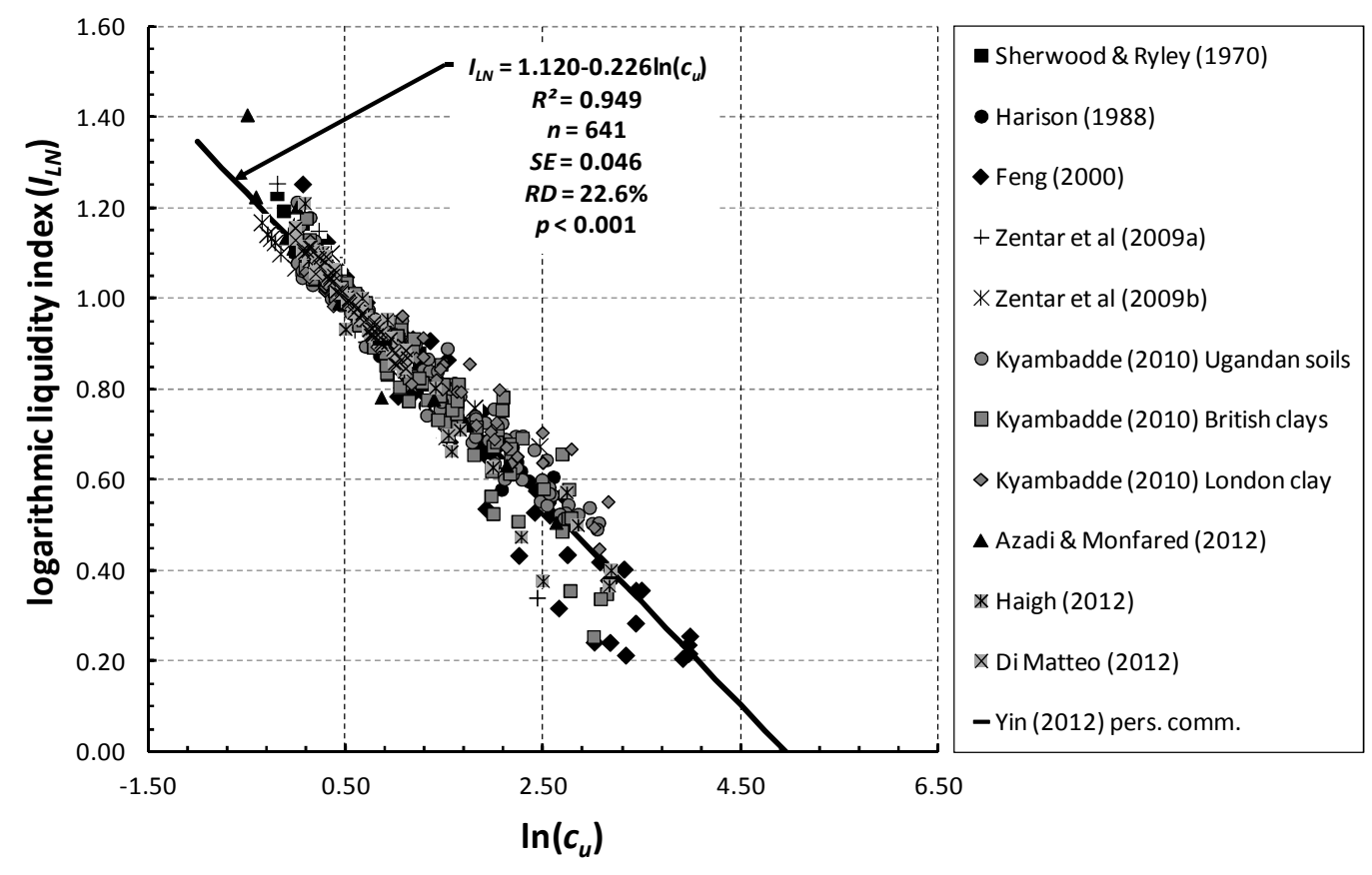




\section{Page 39 of 40}

Figure 8

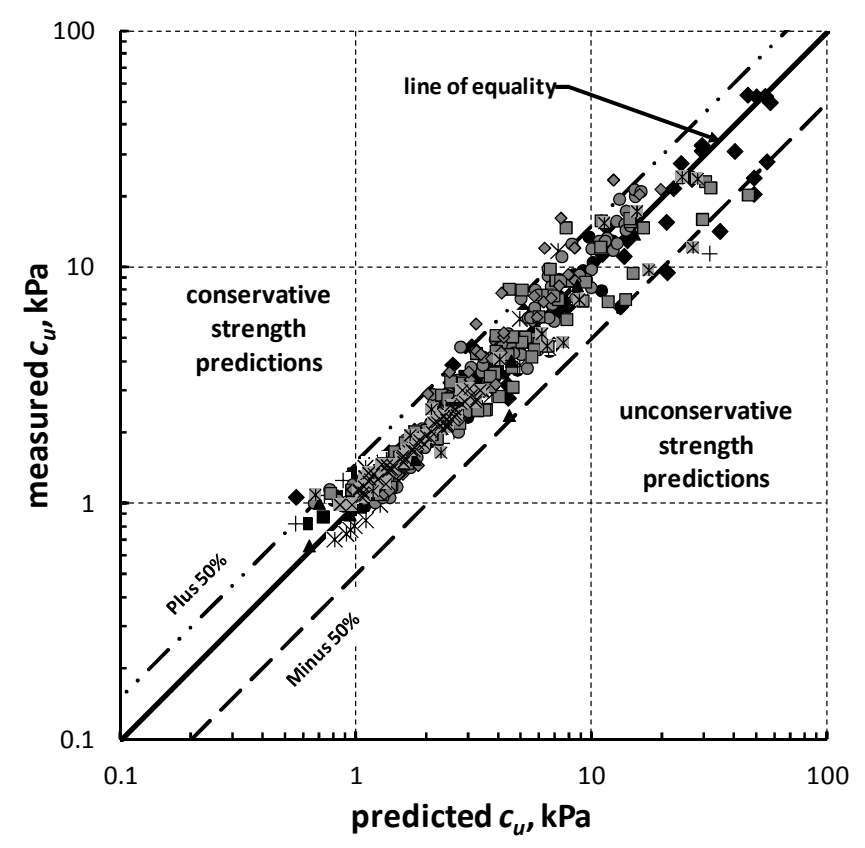

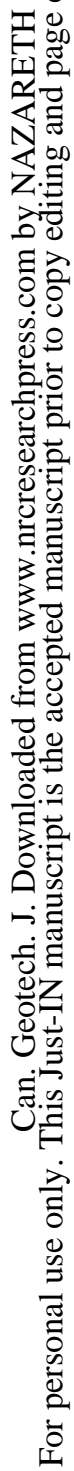


Figure 9

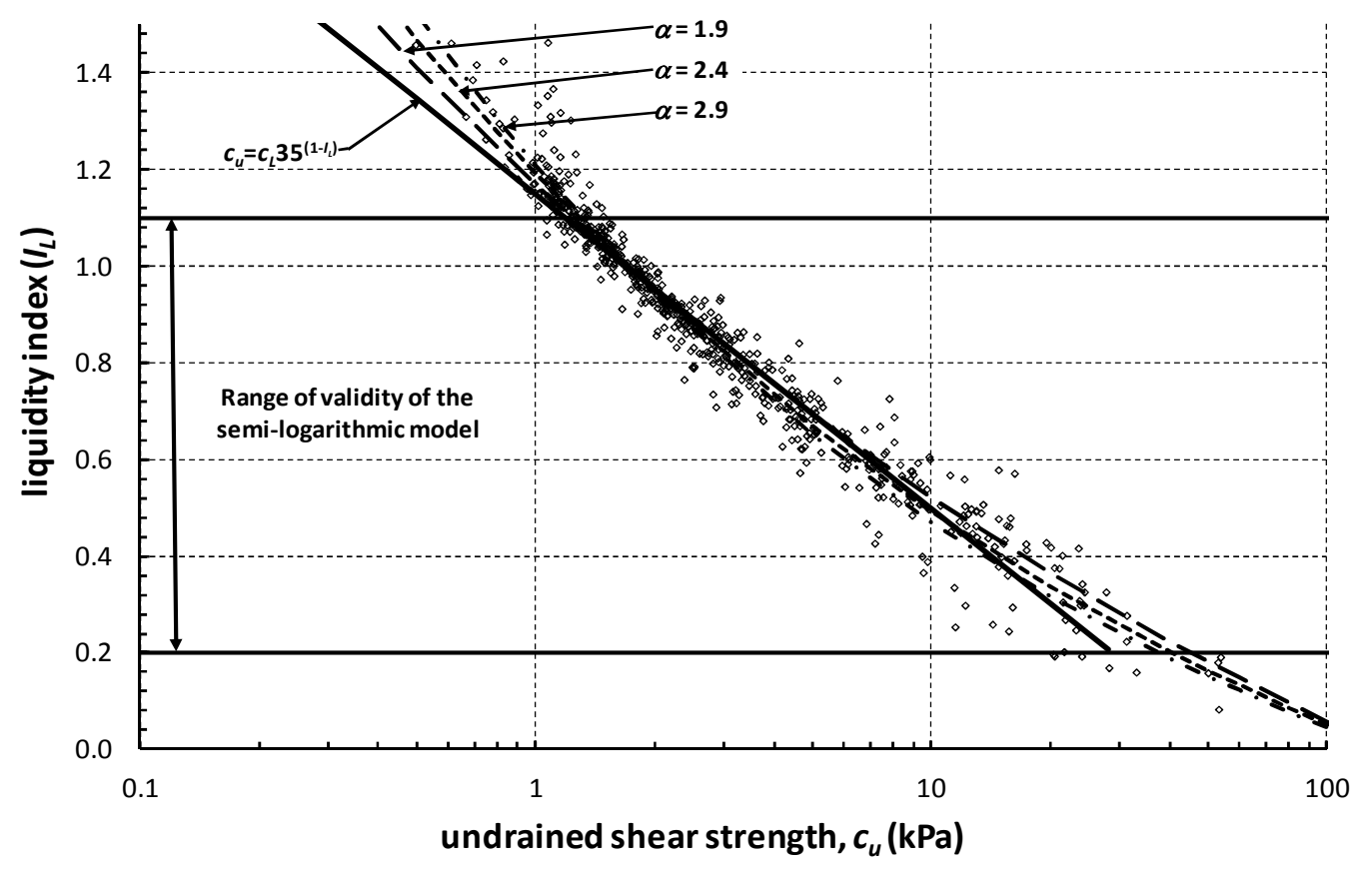

